$12-2003$

\title{
TELRIC vs. Universal Service: A Takings Violation?
}

Stuart Buck

Hughes \& Luce

Follow this and additional works at: https://www.repository.law.indiana.edu/fclj

Part of the Administrative Law Commons, Antitrust and Trade Regulation Commons, Communications Law Commons, Constitutional Law Commons, and the Legislation Commons

\section{Recommended Citation}

Buck, Stuart (2003) "TELRIC vs. Universal Service: A Takings Violation?," Federal Communications Law Journal: Vol. 56 : Iss. 1 , Article 2.

Available at: https://www.repository.law.indiana.edu/fclj/vol56/iss1/2

This Article is brought to you for free and open access by the Law School Journals at Digital Repository @ Maurer Law. It has been accepted for inclusion in Federal Communications Law Journal by an authorized editor of Digital Repository @ Maurer Law. For more information, please contact rvaughan@indiana.edu.

\section{$\Psi$}

JEROME HALL LAW LIBRARY

INDIANA UNIVERSITY

Maurer School of Law
Bloomington 


\section{TELRIC vs. Universal Service: A Takings Violation?}

\section{Stuart Buck*}

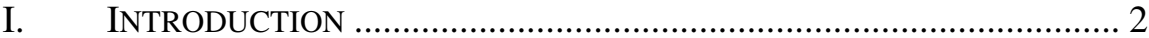

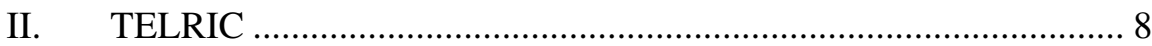

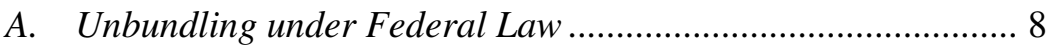

B. The Definition of TELRIC..................................................... 11

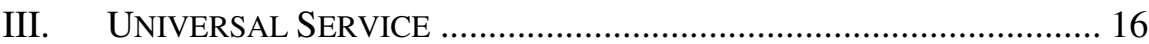

A. Federal and State Law............................................................ 16

B. The Federal and State Universal Service Funds ..................... 23

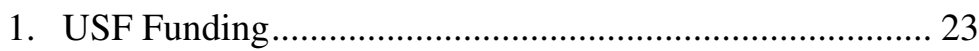

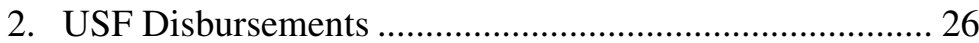

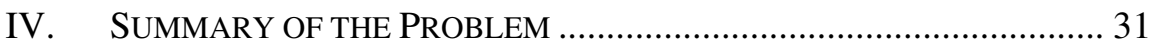

V. CONSTITUTIONAL REMEDIES ........................................................ 33

A. Takings Clause Doctrines................................................... 33

B. The Confiscatory Rate Doctrine-History and Current Applications ............................................................................ 38

C. Recent Developments............................................................... 49

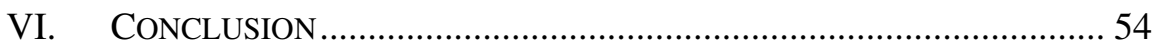

\footnotetext{
* Associate, Hughes \& Luce, Dallas, TX. Former clerk to Judges Stephen F. Williams, D.C. Circuit Court of Appeals, 2001-02, and David A. Nelson, Sixth Circuit Court of Appeals, 2000-01; J.D. with honors, Harvard Law School, 2000. Thanks to Danny Ashby, Bob Davis, Alfred Kahn, Michael Kellogg, and Stephen Williams for their helpful comments.
} 


\section{INTRODUCTION}

By longstanding tradition, local phone companies are required to sell their services to customers at roughly comparable prices. ${ }^{1}$ This so-called "universal service" obligation is intended to ensure that people who live in rural and residential areas (which are expensive to serve) can buy phone service on terms similar to those offered to urban or business customers (which are cheaper to serve). ${ }^{2}$ Under universal service obligations, then, retail pricing is typically averaged across a variety of customers or geographic areas.

The Telecommunications Act of 1996 ("Telecom Act" or "1996 Act"), ${ }^{3}$ however, introduced a new wrinkle into the realm of telecommunications pricing. By law, local telephone companies, known as incumbent local exchange companies ("ILECs"), would be forced to lease virtually all of their equipment and facilities to their competitors, the idea being that the competitors could then offer a competitive product to the consumers. ${ }^{4}$ The pricing terms of such leases are to be set by state public utility commissions, who must calculate the theoretical cost of constructing a new network. This system of cost-based pricing is known as TELRIC, which stands for "total element long-run incremental cost."

While this idea may have had merit standing alone, ${ }^{6}$ the combination of universal service obligations and cost-based wholesale leasing is utterly perverse. It simply makes no sense to require the same company to sell its

1. See infra notes $82-88$ and accompanying text.

2. See infra notes $89-90$ and accompanying text.

3. Telecommunications Act of 1996, 47 U.S.C. § 252(d) (2000).

4. See id.

5. See generally 47 C.F.R. $§ 51.505$ (2002); Id. $§ 51.505$ (a)-(b); Implementation of the Local Competition Provisions in the Telecommunications Act of 1996, First Report and Order, 11 F.C.C.R. 15499, 4 Comm. Reg. (P \& F) 1 (1996) [hereinafter Local Competition Order].

6. Some economists would dispute that conclusion, however. A noted scholar observed long ago, "[T]he very nature of a monopolistic public utility is such as to preclude an attempt to make the emulation of competition very close." JAMES C. BONBRIGHT, PrinCIPLES of Public Utility RATES (1961), quoted in Kenneth Nowotny, The Economics of Public Utility Regulation: An Overview, in Public Utility Regulation: The Economic AND SOCIAL CONTROL OF Industry 9, 19 (Kenneth Nowotny et al. eds., 1989). Alfred Kahn similarly notes that "the notion of requiring a firm to share economies 'equally' with ... outsiders contradicts the essential nature of a firm." ALFRED E. KAHN, WHOM THE GODS Would Destroy, or How Not to Deregulate 19 (2001) [hereinafter Kahn, Whom the GODS WOULD DESTROY]. 
wholesale access at cost, while it must still sell its retail services to all customers at an average price that completely ignores cost. ${ }^{7}$ As the California energy crisis of 2001 showed in painful detail, it is absolutely unworkable to attempt to keep below-cost retail regulation in place while creating a system of at-cost wholesale prices. ${ }^{8}$ The predictable result in California was to "drive the utilities to the point of insolvency." Some analysts predict a similarly gloomy future for the telecom industry. ${ }^{10}$

The following analogy might be instructive: Imagine that Ford had historically been seen as a monopoly provider of automobiles. Imagine further that because of a desire for fairness to all customers, the government had traditionally required Ford to personally deliver cars to all customers' homes at roughly the same price, even if some customers were located right next door to a dealership while others lived a hundred miles from any dealership. This system might be workable as long as Ford was able to use its monopoly power to charge all customers a similar price, such that the next-door customers were essentially subsidizing the far-off customers' delivery.

7. See AT\&T Comm. of the Pac. N.W., Inc. v. U.S. West Comm., Inc., 31 F. Supp. $2 d$ 861,865 (D. Ore. 1998) ("Although the Act contemplates a competitive world in which services are sold on the basis of cost alone, the reality is that we don't yet have a true free market. Rather, we have a hybrid system in which Competitive Local Exchange Carriers ("CLECs") are free to compete but Incumbent Local Exchange Carriers ("ILECs") ... are still subject to extensive restrictions.").

8. As Judge Richard Cudahy of the Seventh Circuit Court of Appeals noted in his analysis of deregulation, California attempted to reduce and then cap retail rates, even while requiring utilities to buy wholesale power on a real-time spot market that more closely tracked actual costs. Richard D. Cudahy, Whither Deregulation: A Look at the Portents, 58 N.Y.U. ANN. SuRV. AM. L. 155, 174-75 (2001). The result was a system that everyone agrees was disastrous, resulting in blackouts and bankruptcies of major companies. Joseph P. Tomain, The Past and Future of Electricity Regulation, 32 ENVTL. L. 435, 439-40 (2002). Even if one assumes that wholesalers were engaged in price gouging in California, the point still remains that it is irrational to have one regulatory approach for retail rates and a completely opposite regulatory approach for wholesale rates.

9. PAul L. Joskow, California's Electricity CRisis 51 (Nat'l Bureau of Econ. Research, Working Paper No. 8442, 2000), available at http://www.nber.org/papers/w8442.

10. See, e.g., Simon Romero, At Telecom Research Firm, the Forecast is Never Sunny, N.Y. TimES, Mar. 17, 2003, at C8 ("'Very few seem to understand that we are on the edge of a financial and business precipice,' Probe [Research] said in the January report. 'If this bear market is prolonged, we fully expect at least one RBOC [regional Bell operating company] to fail. The collapse, like that of the volcano Krakatoa, will be heard around the world, and reverberations will be felt for years."”). 
But then suppose that the government, in an effort to undermine Ford's historic monopoly, ordered Ford to sell all of its automobiles at wholesale, cost-based prices to Chevrolet, who could then relabel the automobiles and resell them immediately. The result would be easy to predict: Chevrolet would buy Ford's autos at the cheap, wholesale prices, and would then target the next-door customers who had historically been relatively overcharged. This, in turn, would undermine Ford's ability to comply with the obligation to deliver automobiles at average prices to rural customers far away from the dealership.

Current telecommunications regulation is roughly equivalent to this hypothetical I have sketched. Local phone companies are being forced simultaneously to provide service at averaged prices to expensive rural customers and to sell wholesale access at cost to their competitors, who can then resell phone service to urban and business customers. This in turn undermines the local phone companies' ability to comply with universal service obligations.

To put things more clearly, here is a simplified model of telecommunications service. Imagine that a state consists of 50,000 urban business customers, 50,000 suburban residential customers, and 10,000 rural customers, all of whom purchase exactly the same service package. The business customers cost $\$ 20$ per month to serve, the suburban customers cost $\$ 40$ per month to serve, and the rural customers cost $\$ 100$ per month to serve. Thus, the total cost of service is $\$ 4$ million per month. As the local phone company is required to charge all customers equal prices for the same service, the price charged to each customer is $\$ 36.36$ per month (4 million divided by 110,000). Thus, the business customers pay an extra $\$ 16.36$ per month, the residential customers get a bargain in the amount of $\$ 3.64$ per month, and the rural customers benefit by $\$ 63.64$ per month.

The viability of this universal service pricing system depends on being able to charge the urban business customers more and the rural customers less. But then enters the 1996 Act, with the requirement that the local phone companies lease their lines and equipment to competitors at cost. Thus, if a competitor comes to the local exchange company and announces that it has signed up all 50,000 urban business customers at some retail price under $\$ 36.36$ per month, the incumbent must lease 50,000 lines to the competitor at the actual cost of $\$ 20$ per month. This then leaves the incumbent serving all the 50,000 suburban customers and the 10,000 
rural customers at a per-customer loss of $\$ 3.64$ and $\$ 63.64$ per month, respectively. (Obviously, the competitors will have little interest in leasing rural lines at the actual cost of $\$ 100$ per month and then selling retail service at $\$ 36.36$.)

Clearly, this is a highly stylized and simplified model because conditions are much more complicated in the real world. Still, this model shows just where the problem lies for the incumbents. On one hand, they are required by law to serve rural customers at prices that do not cover the costs of service. On the other hand, they are now being required to lease lines to competitors at actual cost, who then skim off the most profitable urban business customers ${ }^{11}$ who made the entire system of universal service work in the first place. ${ }^{12}$ As telecom lawyer and scholar Peter Huber recently wrote, "Ordinarily, imperfections in the price-regulating machinery tend to cancel each other out; here, competitors buy wholesale where wholesale is cheaper than retail, and consumers buy retail where retail is cheaper than wholesale. One way or another, incumbent companies end up with sharply lower revenues." 13

But in fact, the problem is even worse than I have suggested thus far. In most states, regulators base retail rates on "value-of-service" calculations, by which rates are actually higher in dense urban areas on the theory that service is more valuable in areas where there are many people to whom one can make local calls. ${ }^{14}$ According to one estimate, businesses are charged at rates of up to four times those charged for the same service in residential areas. ${ }^{15}$ In Rosston and Wimmer's recent analysis of

11. See, e.g., Thomas W. Bonnett, Telewars in the States: Telecommunications ISSUES IN A NEW ERA OF COMPETITION 142 (1996); Joseph D. Kearney \& Thomas W. Merrill, The Great Transformation of Regulated Industries Law, 98 COLUM. L. REV. 1323, 1347 (1998).

12. Again, one might note that the federal government and several states have set up Universal Service Funds ("USFs") that supposedly reimburse carriers for serving high-cost customers. As I argue, however, these USFs are presently not nearly precise and targeted enough to effectively solve the problem. See infra Part III.B.

13. Peter W. Huber, Telecom Undone-A Cautionary Tale, COMMENTARY, Jan. 2003 at 34,38 .

14. See Gregory L. Rosston \& Bradley S. Wimmer, Local Telephone Rate STRUCTURES: Before AND AfTER THE ACT 4-5 (Stanford Inst. for Econ. Pol'y Research, Discussion Paper No. 01-30, (2002)), available at http://siepr.stanford.edu/papers/pdf/ 01-30.pdf [hereinafter ROSSTON \& WIMMER, LOCAL RATE STRUCTURES].

15. Livia Solange West, Deregulating Telecommunications: The Conflict Between Competition and Universal Service, 9 DePaul Bus. L.J. 159, 170 nn.59-60 (1996). See also 
nationwide data, they found that "residential rates are equal to less than one-half the rate paid by business users, holding costs constant," 16 and even that "rates across states are inversely related to costs." 17 To go back to my analogy, this would be as if state law required Ford to charge twice as much for a cross-town delivery as for a cross-country delivery. The incentive for distorted competitive entry would be obvious.

There is little hope for legislative or regulatory relief from this dilemma. Changing the retail rate system is generally thought to be a political nonstarter. ${ }^{18}$ As Robert Saunders pointed out in a recent essay, raising residential rates to market prices

is not an option any company can lobby for without engendering a massive backlash.

Although almost any industry analyst would tell you that Aunt Tilly is simply not paying enough for the telephone services she currently enjoys, it's nigh impossible to convince a lawmaker or regulator of this. No ratepayer wants to pay more, and the PSCs are beholden to powerful folks who listen when large lobbies like the AARP speak. ${ }^{19}$

David L. Kaserman \& John W. Mayo, Cross-Subsidies in Telecommunications: Roadblocks on the Road to More Intelligent Telephone Pricing, 11 YALE J. ON REG. 119, 127-28 (1994) (describing value-of-service pricing) [hereinafter Kaserman \& Mayo].

16. Rosston \& Wimmer, Local RATE Structures, supra note 14, at 4. See also id. at 9, 16 (noting that if costs are held constant, the average residential rate is about forty-five percent of the business rate).

17. Id. at 18 (emphasis added).

18. As Alfred Kahn has said, "However much they may be required for economic efficiency, justified by the non-traffic sensitivity of access costs, and compelled by the pressures of competition, increases in the basic monthly rate are political poison." Alfred E. Kahn, The Road to More Intelligent Telephone Pricing, 1 YALE J. ON REG. 139, 153 (1984). But see Kaserman \& Mayo, supra note 15, at 122 ("Cross-subsidies do not promote universal service, and the political costs of removing them are not as great as some parties have led regulators to believe.").

19. Robert A. Saunders, UNE-P: Regulating Toward the End of the Industry?, TELEPHONY ONLINE, at http://telephonyonline.com/ar/telecom_unep_regulating_toward/ (Sept. 13, 2002). On the other hand, it might be possible to argue that universal service retail pricing fails to provide much benefit to rural users, and that cost-based retail rates would be a net benefit. Some economists have suggested, somewhat surprisingly, that this would be particularly true in more rural states. See, e.g., ROBERT W. CRANDALl \& LEONARD WAVERMAN, Who PAys For Universal SERVICE? 115-123 (2000) [hereinafter CRANDALL \& WAVERMAN]. Nevertheless, that is an issue beyond the scope of this paper. 
Milton Mueller agrees, saying that in the debate over costs, the ultimate trump card is the level of local telephone rates. If basic service rates go up, the FCC will look bad and the new law will appear to the public to be a failure. Thus, the commission's temptation to maintain implicit universal service subsidies or to structure the subsidy program in a way that prevents a cost-based rebalancing of telephone rates is probably irresistible. ${ }^{20}$

Economists confirm that "regulators are mostly influenced by political considerations," primarily "cross subsidization to politically influential user groups." ${ }^{21}$

In order to combat the obvious irrationality of this system, local phone companies may find it necessary to file lawsuits alleging a violation of the Takings Clause of the United States Constitution. Such a suit would claim that the current combination of an averaged retail rate structure and cost-based UNE prices creates a "confiscatory" rate that effectively "takes" their property without just compensation..$^{22}$ Though modern courts are not always in agreement on how to apply the "confiscatory rate" doctrine under the Takings Clause, all agree that the Constitution requires that a

20. Milton Mueller, Universal Service and the Telecommunications Act: Myth Made Law, 40 COMMUNICATIONS 39, 46-47 (1997).

21. Bridger M. Mitchell \& Ingo Vogelsang, Telecommunications Pricing 251 (1991); see also Gerald R. Faulhaber, Voting on Prices: The Political Economy of Regulation, in InTERCONNECTION AND the INTERnet: SEleCted PAPERS FROM THE 1996 Telecommunications Policy Research Conference (Gregory L. Rosston \& David Waterman eds., 1997), available at http://rider.wharton.upenn.edu/ faulhabe/ VotePriceNew.pdf (arguing that pricing set by voter-controlled regulators can actually yield lower total surplus than unregulated monopoly pricing); Robert W. Crandall, Telephone Subsidies, Income Redistribution, and Consumer Welfare, in A COMMUNICATIONS CORNUCOPIA: MARKLE Foundation EsSAys ON Information POLICY 400 (Roger G. Noll \& Monroe E. Price eds., 1998).

For more on the economic theory of regulation, see George J. Stigler, The Theory of Economic Regulation, 2 Bell J. ECON. \& MGMT. SCI. 3 (1971); Richard A. Posner, Taxation by Regulation, 2 Bell J. ECON. \& MGMT. SCI. 22 (1971); Richard A. Posner, Theories of Economic Regulation, 5 Bell J. ECon. \& MGMT. ScI. 335 (1974); Sam Peltzman, Toward a More General Theory of Regulation, 19 J. LAw \& ECON. 211 (1976); Stephen G. Donald \& David E. M. Sappington, Explaining the Choice Among Regulatory Plans in the U.S. Telecommunications Industry, 4 J. ECON. \& MGMT. STRATEGY 237 (1995); David L. Kaserman et al., The Political Economy of Deregulation: The Case of Intrastate Long Distance, 5 J. REG. ECON. 49 (1993).

22. See infra Part V.B. 
company's investors be able to achieve a rate of return reasonably comparable to rates achieved by similar firms with similar levels of risk. ${ }^{23}$

As a famous scholar once commented, "The Supreme Power who conceived gravity, supply and demand, and the double helix must have been absorbed elsewhere when public utility regulation was invented." 24 The recent history of telecommunications regulation does not give much cause for hope, as it attempts to combine two inherently contradictory requirements-universal service retail pricing and cost-based UNE pricing. Because a federal judge would hopefully be isolated from the conflicting political pressures that affect the rationality of decisions by legislators and bureaucrats, a takings lawsuit may well be the most effective way to challenge this confiscatory set of regulations.

\section{TELRIC}

\section{A. Unbundling under Federal Law}

The Telecom Act of 1996 requires, in brief, that incumbent local exchange companies ("ILECs") lease their facilities (i.e., their equipment and resources) to competitive local exchange companies ("CLECs"). ${ }^{25}$ The facilities that ILECs have to lease typically include just about anything that ILECs have-the copper loops that run out to people's houses, the switches that direct calls, the transport lines that carry large volumes of calls from one switch to another, and so forth. When the Federal Communications Commission ("FCC") orders a particular facility to be leased, that facility is said to have been "unbundled," and all such facilities are collectively called "unbundled network elements," or UNEs. ${ }^{26}$

23. Id.

24. F.M. Scherer, Industrial MARKet Structure AND ECONOMic PERFORMANCE 537 (1st ed. 1970), quoted in Gerald W. Brock, Telecommunication Policy for the INFORMATION AGE 20 (1994).

25. See Telecommunications Act of 1996, 47 U.S.C. $\$ 251(c)(6)$ (2000).

26. States typically require the leasing of UNEs as well. Texas law, for example, requires that ILECs unbundle at a minimum to the extent that FCC regulation requires. TEX. UTIL. CoDE ANN. $§ 60.021$ (Vernon 1998). Texas law also purports to authorize the Public Utility Commission to adopt additional unbundling requirements. Id. $\S$ 60.022(a). The question of federal preemption is yet to be settled with regard to such requirements. 
Congress directed the FCC to order unbundling wherever the competitors would be "impaired" without access to the ILECs' facilities. ${ }^{27}$ The FCC's first major attempt to impose massive unbundling ${ }^{28}$ was substantially reversed by the Eighth Circuit in $1997 .{ }^{29}$ On appeal, the Supreme Court held that the Commission's definition of the "necessary" and "impair" standards of $\S 251(\mathrm{~d})(2)$ was improper, cautioning the Commission not to "blind itself to the availability of elements outside the incumbent's network," including self-provisioning and leasing from other providers. ${ }^{30}$ Another problem was that the Commission viewed any increase in the competitor's cost as "impairment." Said the Court, "if Congress had wanted to give blanket access to incumbents' networks, . . . [i]t would simply have said (as the Commission in effect has) that whatever requested element can be provided must be provided." 31

In the UNE Remand Order, ${ }^{32}$ the Commission revised its definition of "impair" so as to require unbundling only if, "taking into consideration the availability of alternative elements outside the incumbent's network, including self-provisioning by a requesting carrier or acquiring an alternative from a third-party supplier, lack of access to that element materially diminishes a requesting carrier's ability to provide the services it seeks to offer." ${ }^{3}$ The Commission also held that under the "impair" standard, it could consider other factors, including whether unbundling would promote "rapid introduction of competition in all markets," promote "facilities-based competition, investment, and innovation," reduce regulatory obligations, promote certainty in the market, and result in administrative practicality. ${ }^{34}$

The elements unbundled by the FCC in that 1999 order included local loops, ${ }^{35}$ subloops, ${ }^{36}$ Network Interface Devices ("NIDs"), ${ }^{37}$ circuit

27. 47 U.S.C. $\$ 251(\mathrm{~d})(2)$.

28. Local Competition Order, supra note 5.

29. Iowa Utils. Bd. v. FCC, 120 F.3d 753 (8th Cir. 1997).

30. AT\&T Corp. v. Iowa Utils. Bd., 525 U.S. 366, 389-90 (1999).

31. Id. at 390 .

32. Implementation of the Local Competition Provisions of the Telecomm. Act of 1996, Third Report and Order and Fourth Further Notice of Proposed Rulemaking, 15 F.C.C.R. 3696, 18 Comm. Reg. (P \& F) 888 (1999).

33. Id. para. 51 .

34. Id. paras. 107-16.

35. Local loops were defined as "all features, functions, and capabilities of the transmission facilities, including dark fiber and attached electronics (except those used for 
switching, ${ }^{38}$ packet switching, ${ }^{39}$ dedicated transport, ${ }^{40}$ shared transport, ${ }^{41}$ signaling networks and call-related databases, ${ }^{42}$ and operations support systems ("OSS"). ${ }^{43}$ Subsequently, however, the D.C. Circuit Court of Appeals overturned the FCC yet again, holding that the agency had failed to provide some sort of limiting standard as the Supreme Court had required. ${ }^{44}$

the provision of advanced services, such as DSLAMs owned by the incumbent LEC, between an incumbent LEC's central office and the loop demarcation point at the customer premises." Id. para. 167. The Commission also required that incumbent LECs "condition" loops to allow CLECs to offer advanced services. Id. para. 172. Conditioning, for these purposes, means removing devices such as bridge taps, low-pass filters, range extenders, etc., that improve voice transmission but may decrease a loop's advanced services capabilities. Id.

36. For example, those "portions of the loop that can be accessed at terminals in the incumbent's outside plant." Id. para. 206. Points of access might include the pole near the customer's premises, the network interface device ("NID"), or the feeder distribution interface (where the trunk line from the central office interfaces with the distribution line to the subscribers). Id.

37. These include "all features, functions, and capabilities of the facilities used to connect the loop distribution plant to the customer premises wiring, regardless of the particular design of the NID mechanism." Id. para. 233.

38. This is defined as "the basic function of connecting lines and trunks," including "all the features, functions and capabilities of the switch." Id. para. 244.

39. This is defined as switching that routes "individual data units based on address or other routing information." Id. para. 302.

40. This is defined as "facilities dedicated to a particular customer or carrier that provide telecommunications between wire centers owned by incumbent LECs or requesting telecommunications carriers, or between switches owned by incumbent LECs or requesting telecommunications carriers." Id. para. 322. The Commission expanded this traditional definition so as to include all high capacity transmission facilities, including DS1 through OC192, as well as dark fiber. $I d$. paras. $323,325$.

41. This is defined as "transmission facilities shared by more than one carrier, including the incumbent LEC, between end office switches, between end office switches and tandem switches, and between tandem switches in the incumbent LEC's network." Id. para. 370.

42. Signaling networks include signaling transfer points, to which each local switch must be connected. Id. paras. 384-86. Call-related databases are "used in signaling networks for billing and collection or the transmission, routing, or other provision of telecommunications service." Id. para. 403. The databases specifically unbundled include the calling name database, the 911 database, the toll-free calling database, and several other databases. Id. para. 410.

43. The OSS consists of "pre-ordering, ordering, provisioning, maintenance and repair, and billing functions supported by an incumbent LEC's databases and information." Id. para. 425.

44. United States Telecomm Ass'n v. FCC, 290 F.3d 415 (D.C. Cir. 2002). 
The FCC extensively reviewed all its unbundling regulations in its Triennial Review rulemaking, ${ }^{45}$ in which the most significant development was that the FCC charged state commissions with making factual findings regarding the competitive "impairment" as to switches (both business and mass-market) and certain types of transport and loops. ${ }^{46}$ This means that state commissions will play a larger role in the future in determining the exact content of unbundling obligations.

In any event, state commissions already play an enormous role in this process by setting the TELRIC prices for the unbundled elements. This role is, in truth, far more important than the decision as to which elements will be unbundled in the first place. The reason for this is straightforward. If the prices set by a state commission are too high, it will not matter how many elements are "unbundled" because the competitive local exchange carriers ("CLECs") will be unwilling to purchase them anyway; rather, they will simply self-provide or else leave the competitive market altogether. On the other hand, if a state commission sets prices too low (which appears more likely in today's regulatory environment), the CLECs will purchase UNEs too often and in too many places, resulting in underprovision of competitive deployment. How state commissions set the TELRIC prices, then, may have more effect on the ultimate unbundling arrangements than anything else.

This, in turn, is why it is so important to ensure that TELRIC prices do not come into direct conflict with other pricing systems that are simultaneously imposed upon the ILECs. But before reaching that point, it is necessary to define TELRIC in fuller detail.

\section{B. The Definition of TELRIC}

The place to begin in defining TELRIC is with the regulation itself, ${ }^{47}$ and the FCC's initial Report and Order setting forth TELRIC. ${ }^{48}$ The regulation defines "forward-looking economic cost of an element" as the sum of "[t]he total element long-run incremental cost of the element,"

45. See Review of the Section 251 Unbundling Obligations of Incumbent Local Exch. Carriers, Report and Order and Order on Remand and Further Notice of Proposed Rulemaking, CC Docket Nos. 01-338, 96-98, 98-147 (Aug. 21, 2003), available at http://www.fcc.gov/Daily_Releases/Daily_Business/2003/db0821/FCC-03-36A1.pdf.

46. See id. para. 7 (executive summary).

47. 47 C.F.R. $\$ 51.505$ (2002).

48. Local Competition Order, supra note 5. 
("TELRIC") and "[a] reasonable allocation of forward-looking common costs." ${ }^{49}$ TELRIC in turn is defined as "the forward-looking cost over the long run of the total quantity of the facilities and functions that are directly attributable to, or reasonably identifiable as incremental to, such element, calculated taking as a given the incumbent LEC's provision of other elements." 50 "Long run" means that the cost must be measured by reference to "a period long enough so that all of a firm's costs become variable or avoidable." 51

The term "forward-looking" rules out any consideration of embedded (or historic) costs, i.e., costs that were incurred in the past when the ILEC set up the facility or element in question. ${ }^{52}$ In one case, a district court approvingly cited a party's distinction:

The forward-looking approach is premised on the fact that the cost of providing facilities today is their replacement cost-the true economic cost that constrains rates in competitive markets—not what was spent in the past. The historic cost approach, by contrast, looks to the company's accounting books and is based on the level of expenditures (less depreciation). ${ }^{53}$

Controversially, the FCC requires an assumption of a maximally efficient network: In calculating "incremental cost," one must assume the "most efficient telecommunications technology currently available and the lowest cost network configuration, given the existing location of the incumbent LEC's wire centers." ${ }^{54}$ What this means, in short, is that when a CLEC buys access to the copper loop that runs into your house, it will (in theory) have to pay the ILEC merely what it would cost to build a brand new copper loop with the most efficient and lowest cost equipment available today, rather than paying to reimburse the ILEC for whatever it spent on building the actual copper loop in question.

Costs that are "causally related" to the element are counted "if the costs are incurred as a direct result of providing the network elements, or can be avoided, in the long run, when the company ceases to provide them." 55

\footnotetext{
49. 47 C.F.R. $\S 51.505(a)$.

50. Id. $\S 51.505(\mathrm{~b})$.

51. Local Competition Order, supra note 5, para. 677.

52. Id. para. 675 .

53. GTE South Inc. v. Morrison, 6 F. Supp. 2d 517, 528 n.8 (E.D. Va. 1998) (citing Brief for AT\&T in Support of Its Motion for Summary Judgment at 12).

54. 47 C.F.R. $\$ 51.505(b)(1)$.

55. Local Competition Order, supra note 5, para. 691.
} 
Moreover, one can include "costs such as certain administrative expenses, which have traditionally been viewed as common costs, if these costs vary with the provision of network elements." ${ }^{56}$ But one cannot include retail, marketing, or billing costs in the forward-looking cost of an element. ${ }^{57}$

Additionally, when calculating incremental cost, the state commission must include the "forward-looking cost of capital" 58 and "economic depreciation rates." 59 As to these portions of "cost," the authorized rate of return at the federal or state level is the default assumption for TELRIC. ${ }^{60}$ If ILECs want to use another rate, they "bear the burden of demonstrating with specificity that the business risks that they face in providing unbundled network elements ... would justify a different risk-adjusted cost of capital or depreciation rate." ${ }^{61}$ The FCC says that "properly designed depreciation schedules should account for expected declines in the value of capital goods." ${ }^{2}$

The FCC elaborates by tying the cost of capital to the statutory provision allowing a "reasonable profit" to the ILECs. ${ }^{63}$ The FCC points out that "normal" profit, in economic terminology, refers to "the total revenue required to cover all of the costs of a firm, including its opportunity costs." 64 The FCC then says, "The concept of normal profit is embodied in forward-looking costs because the forward-looking cost of capital, i.e., the cost of obtaining debt and equity financing, is one of the forward-looking costs of providing the network elements. This forwardlooking cost of capital is equal to a normal profit." ${ }^{.65}$

As for common costs, the FCC explains that "[f]orward-looking common costs are economic costs efficiently incurred in providing a group of elements or services ... that cannot be attributed directly to individual

56. $I d$.

57. $I d$.

58. 47 C.F.R. $\S 51.505(\mathrm{~b})(2)$.

59. Id. $\$ 51.505(\mathrm{~b})(3)$.

60. Local Competition Order, supra note 5, para. 702.

61. Id.

62. Id. para. 686 .

63. Telecommunications Act of 1996, 47 U.S.C. § 252(d)(1) (2000).

64. Local Competition Order, supra note 5, para. 699 ("Economic profit," in turn, is anything above a normal profit.).

65. Id. para. 700 . 
elements or services." ${ }^{66}$ An example would be the salaries of corporate managers, which are incurred as a cost no matter what the mix of goods and services provided. Any common costs (on a forward-looking basis) that are common to a set of elements or services can be allocated to that set. ${ }^{67}$ For example, "shared maintenance facilities and vehicles should be allocated only to the elements that benefit from those facilities and vehicles. ${ }^{96}$ Billing and marketing costs do not count as common costs. ${ }^{69}$ Note that ILECs "shall have the burden to prove the specific nature and magnitude of these forward-looking common costs.",70

The total TELRIC price for an element (i.e., the sum of common costs and incremental costs) cannot exceed the stand-alone costs for that element. ${ }^{71}$ Stand-alone costs are what "would be incurred to produce a given element if that element were provided by an efficient firm that produced nothing but the given element."

I should note that several scholars have argued that TELRIC fails, in and of itself, to compensate ILECs fairly for the use of their resources. ${ }^{73}$ Alfred Kahn, the eminent scholar of regulation, coined the term "TELRICBS," the "BS" purportedly standing for "blank slate."74 Many economists

66. 47 C.F.R. $\S 51.505(\mathrm{c})(1)$ (2002).

67. Local Competition Order, supra note 5, para. 694.

68. Id.

69. Id.

70. Id. para. 695 .

71. 47 C.F.R. $\S 51.505(c)(2)(i)$ (2002).

72. Id.

73. See, e.g., JEAN-JACQUes LAFFont \& JeAn Tirole, Competition in Telecommunications 7-8 (2000); Robert W. Crandall \& Jerry A. Hausman, Competition in U.S. Telecommunication Services: Effects of the 1996 Legislation, in DEREGULATION OF Network Industries 73, 88 (Sam Peltzman \& Clifford Winston eds., 2000) [hereinafter Crandall \& Hausman]; Jerry Hausman, The Effect of Sunk Costs in Telecommunications Regulation, in THE NEW INVESTMENT THEORY OF REAL OPTIONS AND ITS IMPLICATIONS FOR Telecommunications EConomics 191 (James Alleman \& Eli Noam eds., 1999); Mark A. Jamison, Does Practice Follow Principle?: Applying Real Options Principles To Proxy Costs in U.S. Telecommunications, in THE NEW InVESTMENT THEORY OF REAL OPTIONS AND iTS IMPLICATIONS FOR TELECOMMUNICATIONS ECONOMICS 49 (James Alleman \& Eli Noam eds., 1999); Thomas M. Jorde et al., Innovation, Investment, and Unbundling, 17 YALE J. ON REG. 1 (2000). But see David Gabel \& David I. Rosenbaum, Who's Taking Whom: Some Comments and Evidence on the Constitutionality of TELRIC, 52 FED. COMM. L.J. 239, 26768 (2000) (arguing that ILECs' rate of return on regulated investment is high enough not to be a taking).

74. Kahn, WhOM the Gods Would Destroy, supra note 6, at 3. 
instead appear to favor the efficient component pricing rule, ${ }^{75}$ on the grounds that TELRIC understates the most appropriate economic cost of unbundled elements. And the FCC has recently issued a Notice of Proposed Rulemaking that indicates its intent to revise the TELRIC standard so as to be more closely attuned to real world characteristics. ${ }^{76}$

For purposes of this article, however, it is assumed that TELRIC is constitutionally sufficient to compensate the ILECs when considered alone. The real issue here is whether it is constitutional to combine TELRIC wholesale obligations with retail universal service obligations, and if not, how ILECs may effectively remedy the situation. ${ }^{77}$

75. See, e.g., William J. Baumol \& J. GREgORy SidAK, TOWARD COMPETITION IN Local Telephony (1994); J. Gregory Sidak \& Daniel F. Spulber, Deregulatory TAKINGS AND THE Regulatory CONTRACt 283-392 (1998); Mark Armstrong et al., The Access Pricing Problem, 44 J. Indus. ECON. 131 (1996); William J. Baumol et al., Parity Pricing and its Critics: A Necessary Condition for Efficiency in the Provision of Bottleneck Services to Competitors, 14 YALE J. ON REG. 145 (1997); William J. Baumol \& J. Gregory Sidak, The Pricing of Inputs Sold to Competitors, 11 YALE J. ON REG. 171 (1994); Alfred E. Kahn \& William Taylor, The Pricing of Inputs Sold to Competitors, 11 YALE J. ON REG. 225 (1994).

76. See Review of the Comm'n's Rules Regarding the Pricing of Unbundled Network Elements and the Resale of Serv. by Incumbent Local Exch. Carriers, Notice of Proposed Rulemaking, WC Docket No. 03-173, para. 4 (Sept. 15, 2003) ("We seek comment on an approach that bases UNE prices on a cost inquiry that is more firmly rooted in the realworld attributes of the existing network, rather than the speculative attributes of a purely hypothetical network."), available at http://hraunfoss.fcc.gov/edocs_public/attachmatch/ FCC-03-224A1.pdf.

77. ILECs might additionally argue that a state commission misapplied TELRIC so as to fail to compensate an ILEC even for its forward-looking costs. Such a claim would depend on several aspects of the commission's ultimate decision, including how it decides to handle depreciation, cost of capital, fill factors, and other questions. 


\section{UNIVERSAL SERVICE}

\section{A. Federal and State Law}

There are vast disparities between the costs of providing telecommunications services to customers located in different geographic areas (e.g., rural vs. urban). ${ }^{78}$ One set of scholars notes that on average, "residential local rates have been set almost twenty-three dollars per month below their market levels," and that "[i]n some low-density rural areas, ... this difference might be much larger-several hundred dollars per month." 79 Even the FCC acknowledges that "the cost of providing a local loop in a rural area may be approximately one hundred times greater than the cost in an urban area." ${ }^{80}$ The FCC's Joint Federal-State Board on Universal Service observes that "if the urban cost is $\$ 20$, the corresponding rural cost that is one hundred times greater would be approximately \$2000." 81

In any normal competitive market, customers who are more expensive to serve would be charged more, and vice versa. Consistent with decades of regulatory policy ${ }^{82}$ however, both federal and state law require explicitly

78. See, e.g., Emily L. Dawson, Universal Service High-Cost Subsidy Reform: Hindering Cable-Telephony and Other Technological Advancements in Rural and Insular Regions, 53 FED. COMM. L.J. 117, 118 (2000) (noting that "Regions that have fewer customers over which to spread fixed costs, and other factors such as less technologically advanced networks and rugged terrain, have inherently higher service costs.").

79. James Alleman et al., Universal Service: The Poverty of Policy, 71 U. Colo. L. REv. 849, 854 (2000) [hereinafter Alleman et al., Universal Service]. As of their writing, the scholars observed that if "a new local carrier were to enter GTE's serving area in Texas, and attempt to serve all of GTE's local residence customers, it would find that the revenue from all services would fail to cover costs for seventy-eight percent of those customers." Id. at 855.

80. Multi-Ass'n Group (MAG) Plan for Reg. of Interstate Servs. of Non-Price Cap Incumbent Local Exch. Carriers and Interexch. Carriers, Second Report and Order and Further Notice of Proposed Rulemaking in CC Docket No. 00-256, 16 F.C.C.R. 19613, para. 45, 25 Comm. Reg. (P \& F) 1 (2001) (emphasis added) [hereinafter MAG Reg. Plan, Report and Order].

81. Fed.-State Joint Bd. on Universal Serv., Recommended Decision, 17 F.C.C.R. 20716, para. 18, n.52 (2002) [hereinafter Nonrural Recommended Decision].

82. See William P. Cassidy, Jr., Universal Service in a Competitive Telecommunications Environment: The Current State of Universal Service in the European Union and United States, 25 N.C. J. INT'L L. \& COM. REG. 107 (1999) (providing a good background on universal service); Jennifer Hargroves, Adjudication of Universal Funding in the Telecommunications Sector, 79 DENV. U. L. REV. 491 (2002). 
that retail rates be virtually the same in rural and urban areas. The 1996 Act, for example, requires that "[c]onsumers in all regions of the Nation, including low-income consumers and those in rural, insular, and high cost areas, should have access to telecommunications and information services ... at rates that are reasonably comparable to rates charged for similar services in urban areas." 83

State laws typically mirror federal law on this point. For example, Texas requires that urban and rural retail rates be comparable, ${ }^{84}$ that rates for nonmunicipal locations must not be more than $115 \%$ of the rates that the same carrier charges for similar services in municipalities in the same county, ${ }^{85}$ and that an incumbent LEC's rates for interexchange services must be "statewide average rates." 86 California requires that "Universal service shall, to the extent feasible, be provided at affordable prices regardless of linguistic, cultural, ethnic, physical, financial, and geographic considerations." 87 Virginia goes even further, requiring "every public utility to furnish reasonably adequate service and facilities at reasonable and just rates to any person, firm or corporation along its lines desiring same. It shall be their duty to charge uniformly therefor all persons, corporations or municipal corporations using such service under like conditions." 88

The result of universal service obligations is that telephone companies have historically charged some subscribers (usually rural and/or residential) less and some subscribers (usually urban and/or business) more. ${ }^{89}$ To

83. 47 U.S.C. $\$ 254(b)(3)$ (2000). The same provision states that " $[\mathrm{t}]$ here should be specific, predictable and sufficient Federal and State mechanisms to preserve and advance universal service." Id. § 254(b)(5).

84. Tex. Util. Code AnN. § 51.001(g) (Vernon Supp. 2003).

85. Tex. Util. Code AnN. $\$ 53.005$ (Vernon 1998).

86. Id. §53.065(a) (emphasis added).

87. Cal. Pub. Util. Code $§ 883(d)(1)$ (West Supp. 2003); see also id. § 709(a) ("The Legislature hereby finds and declares that the policies for telecommunications in California are as follows: (a) To continue our universal service commitment by assuring the continued affordability and widespread availability of high-quality telecommunications services to all Californians.") (emphasis omitted).

88. VA. Code AnN. § 56-234 (Michie Supp. 2003); see also Wis. Admin. CodE PSC, § 160.02 (13) (2000) ("'Universal service' means a statewide rapid, efficient, communications network with adequate, economically placed facilities to assure that a basic set of essential telecommunications services is available to all persons in this state at affordable prices. ...")

89. See, e.g., Robert W. Crandall \& Thomas W. Hazlett, Telecommunications Policy ReForm IN THE United STATES AND CANADA 18 (AEI-Brookings Joint Center for 
achieve the goal of comparability of rates across urban and rural areas (and hence "universal" service), some form of cross-subsidization is necessary. Indeed, a boilerplate definition of universal service is that it uses "cross subsidies to keep monthly residential rates low by increasing rates for many services (e.g., long distance calls and business rates) to levels that exceed costs." $" 90$

Thus, two aspects of universal service obligations are essential to recognize. First, competitive providers will be naturally drawn to the urban and business markets where ILECs have typically overcharged customers so as to cross-subsidize more expensive rural customers. ${ }^{91}$ Conversely, no competitor in its right mind would try to enter those vastly more expensive rural markets where the customers are already being charged less than cost. Scholars have observed that "the likelihood of entry increases with customer density," and that recent trends show that "entry has indeed

Regulatory Studies, Working Paper No. 00-9, at 18, 2000) (showing that in many American cities, businesses are charged substantially more than residences for single lines) available at http://www.manhattan-institute.org/hazlett/working_00_09.pdf; see also CRANDALL \& WAVERMAN, supra note 19.

90. Gregory L. Rosston \& Bradley S. Wimmer, The ABC's of Universal Service: Arbitrage, Big Bucks, and Competition, 50 HASTINGS L.J. 1585, 1585 (1999) [hereinafter Rosston \& Wimmer, The $A B C$ 's]. An interesting issue that this article does not address is whether this cross-subsidization is inefficient, and hence whether universal service should be abolished quite apart from Takings Clause concerns. Numerous scholars have observed that cross-subsidization is "almost always antithetical to efficient pricing and ultimately to competition.” LaWrence J. White, U.S. Public Policy toward Network INDUSTRIES 32 (1999). See also Milton L. Mueller, JR., Universal Service: Competition, InTERCONNECTION, AND MONOPOLY IN THE MAKING OF THE AMERICAN TELEPHONE SYSTEM 179-80 (1997) (noting the contradiction between unbundling and universal service). According to some measures, cross-subsidization in local phone service likely creates inefficient distortions and welfare losses of $\$ 2.5$ billion to $\$ 7$ billion a year. See Crandall \& Hausman, supra note 73, at 78-79. See also Kaserman \& Mayo, supra note 15 . On the other hand, cross-subsidization by natural monopolies is not necessarily bad; it can be the natural result of Ramsey pricing (a second-best alternative to marginal cost pricing), in which the customers of a multiproduct firm are charged marginal cost plus an amount proportional to the price inelasticity of demand for the product. See, e.g., Kenneth E. TRAin, Optimal Regulation: The ECONOMIC TheORY OF NATURAl MONOPOly 116 (1991). The result might be that some customers (those with a high price elasticity of demand) pay less than the stand-alone cost of the product. Nonetheless, it is fairly clear that universal service pricing is not an example of Ramsey pricing.

91. See, e.g., Alleman et al., Universal Service, supra note 79, at 855; Robert M. Frieden, Universal Service: When Technologies Converge and Regulatory Models Diverge, 13 HARV. J. L. \& TECH. 395, 404 (2000) ("Market entrants predictably target the most profitable and easiest-to-serve customers, typically large-volume business users in cities."). 
largely occurred in high-density nonresidential markets." ${ }^{22}$ The FCC itself has recognized:

[C]ompetitors may be likely to target high-revenue business customers in low-cost urban areas where incumbent LECs are charging rates significantly above costs, while foregoing opportunities to serve lowerrevenue residential customers in high-cost rural areas where incumbent LECs are charging artificially low rates because of implicit support flows. ${ }^{93}$

As a result, "the incentives for competitive entry will necessarily be quite distorted," 94 and the ILECs' ability to fund their still-existing universal service obligations may be severely undermined.

Second, universal service requires averaging of costs across customers. ${ }^{95}$ As the FCC observed, "The urban-to-rural subsidy has been accomplished through the explicit high cost fund mentioned above, and through geographic rate averaging. The result of state requirements that local telephone rates be averaged across the state is that high-density (urban) areas, where costs are typically lower, subsidize low-density (rural) areas." customers pay a lower retail rate than they otherwise would, while lowercost customers pay a higher retail rate. ${ }^{97}$

92. Farid Gasmi et al., Cost Proxy Models and Telecommunications Policy 47 (2002) [hereinafter GASMI ET AL., COST PROXY ModELS].

93. Fed.-State Joint Bd. on Universal Serv., Ninth Report \& Order and Eighteenth Order on Reconsideration, 14 F.C.C.R. 20432, para. 16, 18 Comm. Reg. (P \& F) 710 (1999) [hereinafter Ninth Report \& Order].

94. Robert W. Crandall, Managed Competition in U.S. Telecommunications 9 (AEI-Brookings Joint Center for Regulatory Studies Working Paper No. 99-1, 1999), available at http://aei-brookings.org/admin/pdffiles/working_99_01.pdf.

95. As one scholar notes, the most important source of universal service funding "is geographic rate averaging: high-density urban areas, where costs are lower, underwrite the provision of service to low-density, high-cost rural areas." Jonathan Weinberg, The Internet and "Telecommunications Services," Universal Service Mechanisms, Access Charges, and Other Flotsam of the Regulatory System, 16 YALE J. ON REG. 211, 214 (1999).

96. Fed.-State Joint Bd. on Universal Serv., Report and Order, 12 F.C.C.R. 8776, para. 11, 7 Comm. Reg. (P \& F) 109 (1997) (emphasis added) [hereinafter Report and Order, May 1997]. See also Rosston \& Wimmer, The ABC's supra note 90, at 1599 (noting that regulators rely "on geographically averaged rates to hold rates down in high-cost areas").

97. GASMI ET AL., COST PROXY Models, supra note 92, at 150 ("[T]he objective of universal service technically amounts to imposing uniform pricing across the urban and rural areas despite the difference in the cost of serving a typical customer in those two areas.”). 
This concept of averaging, however, is absolutely contradicted by the FCC's concept of TELRIC rate-setting, which requires a substantial amount of deaveraging. The FCC has concluded that "rates for . . . unbundled elements must be geographically deaveraged" 98 into at least three cost-related rate zones. ${ }^{99}$ CLECs have often sought more extensive deaveraging, but federal courts have generally refused to mandate deaveraging more extensive than that ordered by the FCC. ${ }^{100}$

Geographic deaveraging of UNE prices does nothing but exacerbate all the harmful distortions between the UNE rates and the universal service retail rates. When UNE rates are geographically deaveraged, this means that they will more closely mirror the actual cost of service in a particular region, which will create a greater divergence between wholesale rates and retail rates. This makes it all the easier for CLECs to enter precisely those markets where there is the greatest divergence between UNE rates and retail rates-that is, to cherry-pick profitable urban markets. ${ }^{101}$ As one

98. Local Competition Order, supra note 5, para. 764.

99. Id. para. 765; see also 47 C.F.R. § 51.507(f) (2002) (requiring state commissions "[to] establish different rates for elements in at least three defined geographic areas within the state to reflect geographic cost differences").

In defining the zones, states "may use existing density-related zone pricing plans described in 47 C.F.R. $\$ 69.123$ " or as established under state law, or if no such plan exists, "state commissions must create a minimum of three cost-related rate zones." 47 C.F.R. $\S$ 51.507(f)(1)-(2) (requiring state commissions to "establish different rates for elements in at least three defined geographic areas within the state to reflect geographic cost differences"). Turning to 47 C.F.R. $§ 69.123$ for an example of a density-related zoning rule, one finds that ILECs not subject to price cap regulation are allowed to establish "a reasonable number of density pricing zones" for special access and switched transport, and that these "pricing zones shall be designed to reasonably reflect cost-related characteristics, such as the density of total interstate traffic in central offices located in the respective zones." Id. $\S$ 69.123(a)(1)-(2).

100. See, e.g., U.S. West Comm., Inc. v. Jennings, 304 F.3d 950, 959 (9th Cir. 2002); AT\&T Comm. S. States, Inc. v. GTE Fla., Inc., 123 F. Supp.2d 1318, 1324 (N.D. Fla. 2000); AT\&T Comm. S. States, Inc. v. BellSouth Telecomm., Inc., 122 F. Supp.2d 1305, 1313-14 (N.D. Fla. 2000), rev'd on other grounds, 268 F.3d 1294 (11th Cir. 2001); U.S. West Comm., Inc. v. Jennings, 46 F. Supp. 2d 1004, 1014 (D. Ariz. 1999); MCI Telecomm. Corp. v. BellSouth Telecomm., Inc., 40 F. Supp.2d 416, 424 (E.D. Ky. 1999); MCI Telecomm. Corp. v. GTE N.W., Inc., 41 F. Supp.2d 1157, 1171 \& 1171, n.9 (D. Or. 1999); AT\&T Comm. Pac. N.W., Inc. v. U.S. West Comm., Inc., 31 F. Supp.2d 861, 865 (D. Or. 1998); MCI Telecomm. Corp. v. US West Comm., Inc., 31 F. Supp.2d 859, 860-61 (D. Or. 1998).

101. As one court observed:

If MCI intended to serve a full range of customers through unbundled loops, it likely would not be arguing so strenuously for deaveraging loop prices. 
court said, "Unlike CLECs . . , an ILEC is legally obligated to service all customers within its territory, at the same fixed price. Consequently, MCI and other CLECs could solicit the most profitable customers, leaving the ILEC to service the unprofitable accounts the CLECs do not want."102

\section{Another court stated:}

The Court is aware from the cost studies provided by BellSouth that the expenses of providing local service varies with the density of the population. The Court is also aware that should the PSC geographically deaverage the cost of providing service to customers, the possibility exists that new entrants would only purchase UNEs in urban areas or other lowcost segments of the industry. By purchasing UNEs in this manner, a new entrant could obtain the advantages of serving low overhead areas immediately without dealing with the need to subsidize the more expensive areas. The Court recognizes that remote rural areas which are less densly populated are not terribly attractive to new market entrants. However, their need for service at a reasonable rate is no less important than the need in booming urban areas. It is the opinion of this Court that the PSC's refusal to deaverage was an effort to prevent new entrants from seeking the lowest possible overhead to serve the most lucrative customers.... Therefore, the decision of the PSC to balance universal service goals with the purpose of the Act by refusing to deaverage the UNE rates was lawful. ${ }^{103}$

State commissions have recognized this effect of deaveraging as well. In Vermont, the state commission observed that where there is a zone with "high customer density and low average loop costs," the "UNE loop prices in the urban zone will be significantly lower than UNE loop prices in the rural zone." 104 The commission recognized the danger of further deaveraging: "Following UNE price deaveraging, ... a [CLEC] that serves Burlington and Winooski through UNEs will have lower costs and thus a larger potential profit margin." 105 The Vermont commission went on to

Deaveraging makes financial sense to MCI only if it intends to target primarily the lowest-cost loops, while either (1) leaving the higher-cost loops for GTE to service, or (2) serving those higher-cost customers via the resale route, where the discounted price the CLEC pays to GTE may be less than GTE's actual cost to provide the service.

MCI Telecomm. Corp. v. GTE N.W., Inc., 41 F. Supp.2d at 1171 n.9.

102. Id. at 1171 .

103. MCI Telecomm. Corp. v. BellSouth Telecomm., Inc., 40 F. Supp.2d at 424.

104. Vt. Pub. Serv. Bd., Investigation of Geographically Deaveraged Unbundled Network Prices, Docket No. 6318, at 12 (2000), available at http://www.state.vt.us/psb/orders/2000/files/6318ordregeographicdeaveraging.pdf.

105. Id. 
describe the problem of distorted incentives:

[R]efrain[ing] from imposing broad service obligations on CLECs [would allow] them to "cherry pick" by serving only the most lucrative customers or areas within a UNE zone. This violates the assumption that universal service support should be available only to carriers that are willing to serve costly and difficult-to-serve customers. Selecting this option could slow the diffusion of competition in high-cost rural areas, since CLECs will have no legal obligation and no economic incentive to serve unattractive areas. Refraining from service obligations also violates the assumption that underlies the calculation of an average UNE cost for the zone: that buyers will actually purchase some services in areas where costs are below the price as well as from areas where costs are above the price. CLECs thus would have the opportunity to impose above-average costs on the incumbent by purchasing only expensive facilities at averaged prices. ${ }^{106}$

Creating such a distorted set of incentives makes it impossible to determine whether competitive entry is, in any particular case, desirable or not. Each additional degree of UNE price deaveraging only increases the likelihood that a CLEC might be able to offer lower rates to a business customer in an urban area not because it is more efficient than the ILEC, but simply because it is the unintended beneficiary of public regulation's schizophrenic attempt to retain a system of high rural rates and crosssubsidies while nonetheless deaveraging UNE rates by geography. ${ }^{107}$

This is why deaveraging of UNE prices inherently contradicts the ideal of universal service. ${ }^{108}$ Indeed, this should be obvious from the FCC's stated rationale for deaveraging: "deaveraged rates more closely reflect the

106. Id. at 29 .

107. See Alleman et al., Universal Service, supra note 79 , at 861.

108. See, e.g., Tex. Pub. Util. Comm'N, Report on Scope of Competition in Telecommunications Markets of Texas, at 45 (2001) ("The practice of imposing crosssubsidies is incompatible with the goal of promoting fair competition (i.e., based on real economic costs) via the construction of new facilities by new competitors."), available at http://www.puc.state.tx.us/telecomm/reports/scope/2001/2001scope_tele.pdf; see also West, supra note 15, at 159; Annegret Groebel \& Rainer Schnepfleitner, Geographically Averaged Rates in the Context of Local Loop Unbundling, Paper for the 11th Euro. Reg. Conf., 4 (Sept. 9-11, 2002), available at http://www.tkc.at/web.nsf/lookuid/ f0ea5f3fe2857042c1256cf000548cc0/\$file/geographicallylocalloop.pdf (“[A] deaveraged line rental implies deaveraged tariffs, taking away from the incumbent the opportunity for internal subsidization from low-price to high-price regions. The result is that prices rise in rural areas until costs are recovered whereas prices fall for urban customers due to competition."). 
actual costs of providing interconnection and unbundled elements." ${ }^{109}$ But this principle is flatly contradictory to universal service, which by its very nature requires that high-cost customers be charged rates that do not reflect the actual costs of the services they purchase.

\section{B. The Federal and State Universal Service Funds}

\section{USF Funding}

All of this concern over TELRIC pricing might be ameliorated if ILECs were fairly compensated for their provision of universal service to all customers. And indeed, both the federal government and some state governments have set up Universal Service Funds ("USFs") that purport to reimburse carriers for the expenses of serving expensive customers at below-cost rates. Unfortunately, neither the federal USF nor prominent state USFs succeed in fairly compensating ILECs for this obligation.

The first problem with all types of USFs is the source of funding. It is well known to economists that the least distortionary system of subsidizing any particular activity is usually to take the money from general revenues, so that consumers' patterns of consumption remain proportional. ${ }^{110}$ Neither federal nor state USFs are funded that way. Rather, both types depend on funding from fees paid in equal proportions by all carriers, including the very carriers that are supposed to be subsidized by the USF in question.

Let us take a closer look at the federal high-cost universal service programs first, focusing on two that are most relevant to the theme of this article: ${ }^{111}$

109. Local Competition Order, supra note 5, para. 764 (emphasis added).

110. See, e.g., Jerry Hausman \& Howard Shelanski, Economic Welfare and Telecommunications Regulation: The E-Rate Policy for Universal-Service Subsidies, 16 YALE J. ON REG. 19, 33 (1999); Rosston \& Wimmer, The ABC's, supra note 90 at 1612; Thomas G. Krattenmaker, The Telecommunications Act of 1996, 29 CoNN. L. REv. 123, 165 (1996).

111. The following federal universal service decisions apply to interstate access charges, but are not examined in detail in this paper: MAG Reg. Plan, Report and Order, supra note 80; and Access Charge Reform, Sixth Report and Order in CC Docket Nos. 96-262 and 941, 15 F.C.C.R. 12962, 20 Comm. Reg. (P \& F) 636 (2000). 
(1) The nonrural high-cost support program, which applies to nonrural carriers. ${ }^{12}$ (Nonrural carriers are, quite simply, those who do not meet the narrow statutory definition of an exclusively "rural" carrier. ${ }^{113}$ )

(2) The rural high-cost support program, which provides support for the loop costs faced by rural carriers. ${ }^{114}$

Both programs are generally funded by fees that apply to all carriers based on all their interstate revenues. Under federal law, "[e]very telecommunications carrier that provides interstate telecommunications services shall contribute, on an equitable and nondiscriminatory basis," to the federal fund. ${ }^{115}$ Likewise, FCC regulations that apply to all federal universal support programs state that fees are to be based on "end-user telecommunications revenues, and on a contribution factor determined quarterly by the Commission." 116 The fee for the second quarter of 2003 is approximately nine percent of all such revenues. ${ }^{117}$

State USF programs are similarly constrained by federal law, which provides that every "telecommunications carrier that provides intrastate telecommunications services shall contribute, on an equitable and nondiscriminatory basis, in a manner determined by the State to the

112. See Nonrural Recommended Decision, supra note 81.

113. The 1996 Act defined rural carriers as those who fit within one of four categories: (1) Those who "[provide] . . . service to [a] . . study area that does not include either . . any incorporated place of 10,000 inhabitants or more," or any urban territory; (2) Those who provide exchange service to fewer than 50,000 access lines; (3) Those who "[provide] telephone exchange service to any local exchange carrier study area with fewer than 100,000 access lines"; or (4) Those who "[have] less than 15 percent of [their] access lines in communities of more than 50,000." 47 U.S.C. § 153(37) (2002).

114. Fed.-State Joint Bd. on Universal Serv., Fourteenth Report and Order, 16 F.C.C.R. 11244, 23 Comm. Reg. (P \& F) 1388 (2001) [hereinafter Rural High-Cost Order]. There are two other rural high-cost support programs that I do not discuss in detail here: the Long Term Support and the Local Switching Support programs. As described in the Rural HighCost Order, "LTS provides support for the interstate loop costs of rate-of-return carriers (typically small, rural carriers) ... , and LSS ... is available to support a portion of the switching costs of carriers with 50,000 or fewer lines." Id. para. 13 n.21 (citing 47 C.F.R. $\S \S$ 36.125(b), 54.301, 54.303; Fed.-State Joint Bd. on Universal Serv. Fourth Order on Reconsideration in CC Docket No. 96-45, R13 F.C.C.R. 5318, paras. 40-41, 56-58, 10 Comm. Reg. (P \& F) 1282 (1997)).

115. 47 U.S.C. $\$ 254(d)$.

116. See 47 C.F.R. § 54.709(a) (2002).

117. See Universal Service Administrative Company Chart, available at http://www.universalservice.org/download/pdf/New\%20FCC\%20Methodology\%20Calculat ion\%20Example.pdf (last visited Oct. 15, 2003). 
preservation and advancement of universal service in that State."118 Pursuant to this provision, states generally impose fees that are based on revenues of all carriers in the state.

Texas, for example, imposes a "statewide uniform charge payable by each telecommunications provider that has access to the customer base."119 According to the Commission's rules, the USF charge "shall be payable by all telecommunications providers," 120 based on their "monthly taxable telecommunications receipts." 121 In California, ${ }^{122}$ the public utility commission imposes an "All End User Surcharge," that applies to "all telecommunications providers" and is a "percentage of the customers" [ ] total expenditures on telecommunications services." 123 Similarly, Colorado imposes a contribution fee on all intrastate revenues of all telecommunications providers, ${ }^{124}$ and Pennsylvania employs a complicated formula that calculates fees in proportion to intrastate revenues. ${ }^{125}$

In short, both state and federal USFs tend to be funded by contributions that apply equally to carriers serving both low- and high-cost customers. And if all must contribute equally, it is difficult to see how these USFs can effectively redistribute money from low- to high-cost

118. 47 U.S.C. $\$ 254(\mathrm{f})$ (emphasis added).

119. Tex. Util. Code AnN. § 56.022(a) (Vernon Supp. 2003).

120. P.U.C. SUBST. R. $\S 23.150(\mathrm{~g})(1)$, available at http://www.puc.state.tx.us/ telecomm/reports/txunfund.cfm (last visited Aug. 28, 2003). This is confirmed by the Commission's current website, which states that the Texas system of universal service is funded by a $3.6 \%$ fee on "all telecommunications companies." Tex. Pub. Util. Comm'n, The Texas Universal Service Fund, at http://www.puc.state.tx.us/ocp/telephone/txunivserv.cfm (last modified June 30, 2003) (emphasis added). The Texas Office of Public Utility Counsel also says that the Texas USF charge is "assessed on all Texas local, long distance, pager, wireless, and other telecommunications services." Tex. Universal Serv. Fund, Understanding Your Telephone Bill, at http://www.opc.state.tx.us/phoneb 1.htm (last modified Sept. 8, 2003) (emphasis added).

121. P.U.C. SuBST. R. $\$ 23.150(\mathrm{~g})(2)$. Though the providers may recover the USF charge through a surcharge added to customers' bills, "the surcharge must be assessed as a percentage of every retail customers' bill." Id. $\$ 23.150(\mathrm{~g})(5)(\mathrm{A})(\mathrm{ii})$ (emphasis added).

122. California's main Universal Service Order can be found here: Cal. Pub. Util. Comm'n, Rulemaking on the Commission's Own Motion into Universal Service and to Comply with the Mandates of Assembly Bill 3643, Decision No. 96-10-066, 1996 Cal. PUC LEXIS 1046 (Oct. 25, 1996) [hereinafter Cal. USF Decision].

123. $I d$. at $* 436$.

124. 4 CODE OF COLO. REG. $\S \S$ 723-41-7.1-723-41-7.5 (2003), available at http://www.dora.state.co.us/puc/rules/723-41.pdf.

125. 52 PA. CODE $\S 63.165$ (2001), available at http://www.pabulletin.com/secure/data/ vol31/31-26/1165.html. 
customers. ${ }^{126}$ Rather, the equal contribution requirements dilute the effect of any cross-subsidization and therefore tend to undercompensate carriers that serve high-cost or rural areas.

\section{USF Disbursements}

If a USF were to properly compensate incumbent carriers for the costs of serving expensive areas, it would have to be structured something like this:

1) The average cost for residential and business wire centers should be computed.

2) All contributions to the state USF should come only from fees leveled on service provided in wire centers (or some other configuration) in which the cost is below the average cost for the service in question.

3) All USF funding should flow only to companies providing service to wire centers in which the costs exceed the average residential or business cost, and should cover any discrepancy between cost of service (including a contribution to the firm's joint and common costs) and the retail rates mandated by state law.

4) No reductions in other fees or charges should be required from any carrier receiving disbursements from the USF.

Such a system of funding and disbursement would mimic the crosssubsidization that a single ILEC was able to accomplish in the past. Customers in low-cost, urban areas would inevitably be charged a higher rate for service, and the funds would be used to cross-subsidize operations in high-cost, rural areas.

The way that federal and state USF programs disburse funds is nothing like the above. Neither type of fund appears to provide anything resembling full compensation for those incumbent carriers who serve highcost, rural customers.

126. It is mathematically possible, of course, to design an equal percentage fee that, given a particular balance between high- and low-cost customers, is capable of refunding all the money paid by high-cost customers along with enough to make up the difference between costs of service and retail rates for those high-cost customers. But no evidence seems to exist to show that any state commission has mandated a contribution fee based on any such calculation, and it seems a senseless exercise to require high-cost customers to pay a fee into a program that is supposedly designed to reimburse their own carriers for serving them. 
Regarding nonrural carriers (which are most relevant to this article), the FCC views its task to be the equalization of funds at the state level. That is, some states face higher telecommunications costs, on average, than other states, and the FCC views it as its job to use the USF programs to redistribute money from the low- to the high-cost states. As the Joint Board said in its most recent recommended decision as to nonrural carriers, "nonrural high-cost support is designed to provide high-cost states enough support so that their net average costs are reasonably comparable to the national average cost." 127

Thus, the high-cost support program for nonrural carriers is likely to distribute funds as follows: ${ }^{128}$ The FCC will continue to calculate the overall average cost per line for nonrural carriers on a statewide basis. ${ }^{129}$ It will then calculate the average nationwide cost per line. ${ }^{130} \mathrm{~A}$ few states will have average per-line costs that exceed two standard deviations above the national average- the FCC's new requirement for funding eligibility. ${ }^{131}$ Standard statistics tells us that two standard deviations above average is equivalent to approximately the 98th percentile. This means that only those

127. Nonrural Recommended Decision, supra note 81 , para. 15.

128. The term "likely" was used because this program has had a checkered history. See Ninth Report \& Order, supra note 93, overruled by Qwest Corp. v. FCC, 258 F.3d 1191, 1201-03 (10th Cir. 2001). The Ninth Report \& Order was struck down chiefly on the grounds that the FCC had failed to assure that rural and urban rates would be reasonably comparable and had failed to present data to support its use of the $135 \%$ benchmark. Id. at 1195. The Joint Board issued a recommended decision later in 2002 that responded to the Tenth Circuit's concerns, see Nonrural Recommended Decision, supra note 81. The FCC then issued an NPRM seeking comments on whether this recommended decision should be enshrined in law. Fed.-State Joint Bd. on Universal Serv., Notice of Proposed Rulemaking, 18 F.C.C.R. 2932 (2003). At the time of this writing, the safest assumption seems to be that whatever rule the FCC eventually adopts will be closely akin to the recommended decision of October 2002. On October 16, 2003, the FCC issued a press release announcing a forthcoming order that "largely adopts the recommendations of the Federal-State Joint Board on Universal Service." Press Release, FCC, FCC Modifies High-Cost Support Mechanism But Maintains Current Support Levels (Oct. 16, 2003), available at http://hraunfoss.fcc.gov/edocs_public/attachmatch/DOC-240035A1.pdf [hereinafter FCC Press Release, Oct. 16].

129. Nonrural Recommended Decision, supra note 81, para. 24.

130. Id. para. 30, available at http://hraunfoss.fcc.gov/edocs_public/attachmatch/FCC02J-2A1.pdf.

131. The new USF Order "[m]odifies the high-cost mechanism for non-rural carriers by basing the cost benchmark-which is used to determine the amount of support-on two standard deviations above the national average cost per line." FCC Press Release, Oct. 16, supra note 128 . 
states whose average cost is higher than $97.5 \%$ of the national average will receive high-cost support in the future. As of the first quarter of 2002, the only states in which carriers received USF funding were Alaska, Kentucky, Maine, Mississippi, Montana, Vermont, West Virginia, and Wyoming. ${ }^{132}$ With the FCC's new "two standard deviation" requirement, one can expect that a similarly small number of states will be eligible for USF funding. Indeed, the Universal Service Administrative Company projects that in the fourth quarter of 2003, the only states that will receive high-cost support are Alabama, Kentucky, Maine, Mississippi, Montana, Vermont, West Virginia, and Wyoming. ${ }^{133}$

In most states, therefore, carriers are not even eligible to receive federal nonrural USF funding. Thus, federal nonrural USF funding cannot possibly make up for any disparities that such ILECs might experience.

As for the federal rural carrier USF, it distributes funds as follows: First, the FCC looks at calculations of The FCC begins by calculating embedded, historical costs averaged over so-called "study areas."134 Carriers then receive support for a certain percentage of their loop costs, "depending on the number of loops they serve and the degree to which their costs exceed the national average cost per loop." 135 The growth in total nationwide subsidization from year to year is limited to the percentage growth in the number of working rural loops nationwide. ${ }^{136}$ Specifically, a carrier will receive support only if its embedded loop costs for a study area are more than $115 \%$ of the national average loop cost, ${ }^{137}$ which the FCC estimates to be $\$ 240 .{ }^{138}$

132. Universal Serv. Fund, FCC, Estimated Annual Support Amounts Based on Projections for 1st Quarter, 2002, at http://hraunfoss.fcc.gov/edocs_public/attachmatch/DA01-2927A2.pdf (last visited Oct. 2, 2003).

133. Universal Serv. Admin. Co., High Cost Support Projected by State-4Q2003, at http://universalservice.org/overview/filings/2003/Q4/HC02\%20-\%20High\%20Cost\% 20Support\%20Projected\%20by\%20State\%20-\%204Q2003\%20.xls (last visited Oct. 21, 2003).

134. Rural High-Cost Order, supra note 114, paras. 13, 25.

135. Id. para. 13 (citing 47 C.F.R. $\S 36.601$ et seq.).

136. Id. paras. 31,48 .

137. Id. para. 54 (citing 47 C.F.R. $\S \S 36.601-36.631$ ).

138. Id. para. 55. Support varies in percentage terms by the number of total loops served by the carrier. $I d$. paras. 63,63 n. 167 . 
In short, federal USF programs disburse funds only to carriers whose costs are grossly in excess of the national average. The inevitable result of this is that many carriers in many areas are not compensated in any meaningful fashion for their service of high-cost areas. This is most amply demonstrated by the fact that nonrural carriers in 42 states are ineligible for federal high-cost support.

State systems of USF disbursement are generally no better. The Texas USF system, established on January 14, 2000, ${ }^{139}$ is an exemplar of how state USFs usually work in this regard. Texas calculates revenue benchmarks for both residential and business customers. ${ }^{140}$ These benchmarks are calculated by taking the yearly sum of revenues (statewide) from local services and a reasonable portion of toll and access services, and then dividing by the average number of lines served during that period. ${ }^{141}$

The Texas commission then uses a cost proxy model to determine the forward-looking economic cost ("FLEC") for each wire center. ${ }^{142}$ If the forward-looking cost for a wire center is above the average statewide revenue benchmark, the difference is termed the monthly per-line support amount ("MPLS amount"). Every month, each carrier's support amount is therefore equal to the number of eligible lines in each high-cost wire center multiplied by the MPLS amount for that wire center. ${ }^{143}$

Notably, the amount that any carrier can receive is automatically reduced by any amount that the carrier receives from the federal USF program. ${ }^{144}$ More damaging, though, is that whenever a carrier receives disbursements from the Texas USF, it must make equal and commensurate reductions in other rates, including switched access charges and intraLATA

139. See Tex. Pub. Util. Comm'n, Compliance Proceeding for Implementation of the Texas High Cost Universal Service Plan, Docket No. 18515 (Jan. 14, 2000) [hereinafter Texas USF Order], available at http://interchange.puc.state.tx.us/.

140. See P.U.C. Subst. R. 26.403(e)(1)(B) (2003), available at http://www.puc.state.tx.us/rules/subrules/telecom/26.403/26.403.pdf.

141. See Texas USF Order, supra note 139, at 97.

142. Id. at 92 (citing P.U.C. SUBST. R. 26.403(e)(1)(A)).

143. Id.. More complicated rules come into play when the carrier receiving USF support has obtained facilities through the lease of UNEs from an ILEC. See, e.g., id. at 99-100; see also Tex. Pub. Util. Comm'n, Rulemaking to Amend USF Rules Regarding Unbundled Network Element Sharing Mechanism, Project No. 24526 (2003), available at http://www.puc.state.tx.us/rules/subrules/telecom/26.403/26.403.pdf.

144. Texas USF Order, supra note 139, at 99; P.U.C. SuBST. R. 26.403(e)(3)(B). 
toll rates. ${ }^{145}$ In the PUC's words, "Without such reductions, companies would receive a windfall by virtue of THCUSP implementation." 146

California's Universal Service program is run in almost the same way. California set up the California High Cost Fund-B ("CHCF-B") ${ }^{147}$ to reimburse local exchange companies for serving high-cost areas, ${ }^{148}$ determined by using a proxy cost model that shows which areas exceed the statewide average cost of service. ${ }^{149}$ Just as in Texas, California announced, "In order to avoid a windfall to the five large and mid-size LECs, any subsidy support received from the CHCF-B shall be reduced by the same amount through an equal percentage reduction for all services except for basic service rates." 150

Similarly, in Colorado, the Commission requires that any "Eligible Provider" who hopes to receive compensation from the high-cost fund shall file "rates or prices that will lower its overall regulated revenues in an amount equal to the sum of" support from the Colorado and federal USFs. ${ }^{151}$

It is difficult to see just what benefit any carrier serving a high-cost area could possibly receive from such a system. Such an ILEC will be forced to contribute to the USF based on revenues collected there, and any USF support it receives must be countered by a reduction in other rates. The overall effect is a complete wash.

The California Commission did attempt to justify this restriction by suggesting that if ILECs did not lower their other rates, they might, in effect, be compensated twice for the cost of serving high-cost areas-once

145. Texas USF Order, supra note 139, at 55, 101; P.U.C. SUBST. R. 26.417(c)(2)(A), available at http://www.puc.state.tx.us/rules/subrules/telecom/26.417/26.417.pdf.

146. Texas USF Order, supra note 139 , at 55, 101. Note also that any utility holding a certificate of operating authority or a service provider certificate of operating authority "may not charge a higher amount" for switched access than the "holder of the certificate of convenience and necessity in whose territory the call originated or terminated." TEX. UTIL. CODE ANN. § 52.155(a) (Vernon 2003). Thus, if an ILEC is forced to lower its switched access charges due to disbursements from the USF, other smaller rural providers may be forced to match the ILEC's switched access charges as well. This might provide an incentive for them to ally with the ILEC in challenging this provision.

147. See Cal. USF Decision, supra note 122 , at *4.

148. Id.

149. $I d$. at $* 5$.

150. $I d$. at $* 4$.

151. 4 Colo. CODE Regs. $\$$ 723-41-8.7.2 (2003), available at http://www.dora.state.co.us/puc/rules/723-41.pdf. 
from the state USF support system, and once from higher-than-cost rates imposed on other customers. ${ }^{152}$ In other words, the assumption seems to be that ILECs will still be able, even in a competitive marketplace, to keep charging rates (either for other services or to other customers) that are higher than the cost structure would justify.

But this assumption makes no sense. Urban business customers have often been relatively overcharged, for example, as a means of crosssubsidizing higher-cost service in other areas for other customers. In today's competitive marketplace, those are precisely the customers and areas that the CLECs are targeting and will continue to target as long as there is any gap between the historic rates and the costs of service. Thus, given competition, the ILECs will, in short time, be unable to charge higher-than-cost rates anyway. This means that there is little to no risk of any windfall from giving unconditional compensation out of a universal service fund.

\section{SUMMARY OF THE PROBLEM}

The problem is simple: It is flatly incoherent for the state and federal governments to use one set of regulations for wholesale prices (deaveraged TELRIC rates) and a completely opposite set of regulations for retail prices (averaged universal service rates).

Scholars generally agree that competition in the telecommunications market is inconsistent with universal service obligations. ${ }^{153}$ As one scholar noted:

The presence of competition in local telecommunications markets ... will eventually eliminate any cross-subsidies that governmental authorities have built into the existing regulated rate structure, such as the subsidization of residential customers by business customers. If competitors are as efficient as the RBOCs, then the RBOC cannot set the price for any service at a level above the stand-alone costs of

152. Cal. USF Decision, supra note 122 , at $* 315$ ("[I]n order to make subsidies for high cost areas explicit, there must be a correlating downward adjustment of rates or price caps ... so as to prevent the LECs from recovering implicit subsidy support as well.").

153. See, e.g., Frieden, supra note 91, at 404; Daniel F. Spulber, Deregulating Telecommunications, 12 YALE J. ON REG. 25, 62 (1995) [hereinafter Spulber]; Rosston \& Wimmer, The ABC's, supra note 90, at 1598-99; West, supra note 15, at 161. 
providing that service. If an RBOC attempted to do so, a competitor could profitably enter that market and provide the service on a standalone basis or in conjunction with other services. ${ }^{154}$

As the FCC has observed, "The result of state requirements that local telephone rates be averaged across the state is that high-density (urban) areas, where costs are typically lower, subsidize low-density (rural) areas." ${ }^{155}$ Thus, the very concept of universal service requires that some customers are being charged less than the actual costs of their service, and the money that makes up the difference has to come from somewhere. If that money does not come from federal or state USFs, the ILEC serving the expensive customers must make up the difference. And if, because of the competitive provisions of the 1996 Act, the ILEC is unable to charge urban/business customers at historic retail rates, the money will come out of the ILEC's bottom line. ${ }^{156}$

154. Spulber, supra note 153 , at 62 . Even the Supreme Court has observed that the two goals are in conflict:

Currently, state laws require local phone rates to include a "universal service" subsidy. Business customers, for whom the cost of service is relatively low, are charged significantly above cost to subsidize service to rural and residential customers, for whom the cost of service is relatively high. Because this universalservice subsidy is built into retail rates, it is passed on to carriers who enter the market through the resale provision. Carriers who purchase network elements at cost, however, avoid the subsidy altogether and can lure business customers away from incumbents by offering rates closer to cost. This, of course, would leave the incumbents holding the bag for universal service.

AT\&T Corp. v. Iowa Utils. Bd., 525 U.S. 366, 393 (1999). The Court went on to say that its remand of the FCC's unbundling rule "may render the incumbents' concern on this score academic." Id. But as we now know, the FCC returned shortly thereafter with an unbundling rule that, as the D.C. Circuit noted, was in several respects actually broader than the rule that the Supreme Court found too broad. United States Telecom Ass'n v. FCC, 290 F.3d 415, 420-21 (D.C. Cir. 2002). The Court also observed, in dicta, that because Section 254 "requires that universal-service subsidies be phased out," the "possibility of arbitrage . . will be only temporary." Iowa Utils. Bd., 525 U.S. at 393-94.

155. Report and Order, May 1997, supra note 96 para. 11. See also Rosston \& Wimmer, The $A B C$ 's, supra note 90, at 1599 (noting that regulators "rel[y] on geographically averaged rates to hold rates down in high-cost areas").

156. Gasmi et al. observe that in modeling a competitive scenario where a CLEC captures half the urban area and the incumbent serves the other half and the entire rural area, "the incumbent has to match the entrant's (average-cost) price in the urban area and apply that same price in the rural area because of the obligation to offer service at affordable prices. This implies a deficit. ..." GASMI ET AL., COST PROXY MOdELs, supra note 92, at 145 (emphasis added). 
In short, ILECs are being forced simultaneously to sell the UNE platform at cut-rate, cost-based, hypothetically-most-efficient, geographically-deaveraged prices to their competitors, while selling their retail service to end-user customers at averaged, universal service prices that in many areas cannot possibly cover the costs of service. As time marches on, and CLECs cream-skim the low-cost urban markets, the ILECs will be in an even more inequitable position-they will be left serving the high-cost, unattractive customers but unable to make up the difference by serving the low-cost customers as well. The problem will be exacerbated in those states with value-of-service retail pricing, wherein there is an even greater margin of profit (and hence a greater incentive) for competitors to target urban businesses. And ILECs will still be forced to contribute to federal USFs that provide little compensation in return, as well as state USFs that may make disbursements only if the ILEC agrees to reduce other charges. In every possible respect, the current system of rate regulation and USF funding/distribution is unfair to the ILECs.

\section{CONSTITUtional REMEDIES}

\section{A. Takings Clause Doctrines}

The constitutional provision typically used to challenge rate setting is the Takings Clause, which provides that "[private] property shall not be taken for public use without just compensation."157 The foundational principle of the Takings Clause is that the government should not force "some people alone to bear public burdens which, in all fairness and justice, should be borne by the public as a whole." 158

157. Chicago, Burlington \& Quincy Ry. Co. v. Chicago, 166 U.S. 226, 236 (1897). The Takings Clause applies to the states via the Fourteenth Amendment, though there is some confusion over whether that originally occurred through the Due Process Clause or the Equal Protection Clause. Chicago, which relied on the Due Process Clause, is the case most often cited as having incorporated the Takings Clause. See, e.g., First English Evangelical Lutheran Church v. County of Los Angeles, 482 U.S. 304, 310 n.4 (1987) (citing Chicago for incorporation); see also Williamson County Reg'l Planning Comm'n v. Hamilton Bank, 473 U.S. 172, 175 n.1 (1985) (also citing Chicago). In an 1894 case, however, the Court opined that "The equal protection of the laws which, by the Fourteenth Amendment, no State can deny to the individual, forbids legislation... by which the property of one individual is, without compensation wrested from him for the benefit of another, or of the public.” Reagan v. Farmers' Loan \& Trust Co., 154 U.S. 362, 399 (1894).

158. Armstrong v. United States, 364 U.S. 40, 49 (1960). 
As for the availability of relief under other constitutional provisions, it is worth noting in passing that early takings cases relied not only on the Takings Clause, but also on the Due Process and Equal Protection Clauses of the Fourteenth Amendment. ${ }^{159}$ And the Fifth Circuit has held that a deprivation of property may give rise to both a takings claim and a substantive due process claim. ${ }^{160}$ Nevertheless, it seems fairly clear that the Takings Clause is the most appropriate doctrinal hook for modern takings claims. ${ }^{161}$ As the First Circuit has noted in a case involving confiscatory price caps on gasoline producers, "recent cases from the Supreme Court seem to suggest a strong preference for a takings analysis in such a situation." 162 Moreover, the Takings Clause is much more likely to provide a winning claim than either the Due Process or Equal Protection Clauses, both of which are rarely used to strike down economic legislation. ${ }^{163}$

159. See, e.g., Covington \& Lexington Turnpike Rd. Co. v. Sandford, 164 U.S. 578, $592-$ 93 (1896); St. Louis \& San Francisco Ry. Co. v. Gill, 156 U.S. 649, 657-58 (1895); Reagan, 154 U.S. at 399; Chicago, Milwaukee \& St. Paul Ry. Co. v. Minnesota, 134 U.S. 418, 458 (1890).

160. See John Corp. v. City of Houston, 214 F.3d 573, 583 (5th Cir. 2000).

161. Moreover, if a lawsuit were filed in the Court of Federal Claims, no such claims could be included anyway. As that court has said, "It is well settled, that [under the Tucker Act, the Court of Federal Claims] . . . has no jurisdiction over claims based upon the Due Process and Equal Protection guarantees of the Fifth Amendment, because these constitutional provisions do not obligate the Federal Government to pay money damages.", Bellamy v. United States, 7 Cl. Ct. 720, 723 (Cl. Ct. 1985) (citations omitted); see also Clark v. Library of Cong., 750 F.2d 89, 103 n.31 (D.C. Cir. 1984) ("The courts have uniformly held that jurisdiction under the 'founded upon the constitution' grant of the Tucker Act is limited to claims under the 'takings clause' of the Fifth Amendment.").

162. Tenoco Oil Co. v. Dep't of Consumer Affairs, 876 F.2d 1013, 1023 (1st Cir. 1989); see also id. at 1020 ("The constitutional requirement that rates be just and reasonable has apparently moved from the protection of the due process clause to that of the takings clause."). As the Supreme Court held in a Fourth Amendment case, where the Constitution "provides an explicit textual source of constitutional protection ... , that Amendment, not the more generalized notion of 'substantive due process,' must be the guide for analyzing these claims.” Graham v. Connor, 490 U.S. 386, 395 (1989); see also Forseth v. Village of Sussex, 199 F.3d 363, 369 n.8 (7th Cir. 2000); Villas of Lake Jackson, Ltd. v. Leon County, 121 F.3d 610, 613-14 (11th Cir. 1997) (“"[G]oes too far' means so far that the regulation constitutes a Takings Clause taking under one of the various standards set forth in recent Supreme Court decisions, not a substantive due process violation."); Armendariz v. Penman, 75 F.3d 1311, 1325-26 (9th Cir. 1996).

163. See, e.g., Ferguson v. Skrupa, 372 U.S. 726, 730 (1963). In modern terms, the court must ask if any conceivable set of facts has a rational relationship to the government's legitimate ends. See, e.g., In re Permian Basin Area Rate Cases, 390 U.S. 747, 769-70 (1968) (quoting Nebbia v. New York, 291 U.S. 502, 539 (1934)); Williamson v. Lee 
The Takings Clause, then, is the most appropriate home for a constitutional challenge to the system of telecommunications pricing. ${ }^{164}$ The next choice is between the various subdoctrines that have arisen under the Takings Clause.

First, there is the physical takings doctrine, which requires a showing that some physical piece of property has been directly appropriated by the government. ${ }^{165}$ To the extent that a takings claim included a challenge at TELRIC, one might argue that the 1996 Act's requirement of "nondiscriminatory access to network elements on an unbundled basis,"166 amounted to a per se physical taking under Loretto $v$. Teleprompter Manhattan CATV Corp. ${ }^{167}$ Such a claim would find some precedent in the

Optical, Inc., 348 U.S. 483 (1955); United States v. Carolene Prods. Co., 304 U.S. 144, 154 (1938). The Supreme Court has observed that takings claims receive higher scrutiny than substantive due process or equal protection claims as to economic legislation. See Nollan v. Calif. Coastal Comm'n, 483 U.S. 825, 834-35 n.3 (1987).

164. One might also argue for the inclusion of statutory claims as well. For example, federal law requires that "[a]ll charges, practices, classifications, and regulations for and in connection with such communication service, shall be just and reasonable." 47 U.S.C. § 201(b) (2000); see also 47 U.S.C. § 205(a) ("[T]he Commission is authorized and empowered to determine and prescribe what will be the just and reasonable charge."); 47 U.S.C. \& 252(d)(1) (noting that the state commissions shall determine the "just and reasonable rate for the interconnection of facilities and equipment"). Such a claim would add little, however, to the constitutional claim. In construing statutes that require a "reasonable rate," the Court has noted that "the 'lowest reasonable rate' is one which is not confiscatory in the constitutional sense." Fed. Power Comm'n v. Natural Gas Pipeline Co., 315 U.S. 575, 585 (1942). The Court has also held that the "just and reasonable standard of the Natural Gas Act 'coincides' with the applicable constitutional standards." Permian Basin Area Rate Cases, 390 U.S. at 770 (1968). Assuming that the language in the Telecom Act is interpreted like that of the Natural Gas Act, any statutory challenge would likely be coterminous with the constitutional challenge. See Ill. Bell Tel. Co. v. FCC, 988 F.2d 1254, 1260 (D.C. Cir. 1993) (noting that "the critical determination in both matters is essentially the same"); see also Jim Chen, The Second Coming of Smyth v. Ames, 77 TEx. L. REv. 1535, 1549 (1999) ("The statutory standard for setting 'just and reasonable' rates so closely tracks the constitutional constraints against confiscatory ratemaking that the usual preference for statutory over constitutional decisions poses no real barrier to a constitutional ruling on TELRIC.") (footnotes omitted).

165. Some have argued that the Takings Clause, as originally understood, applied only to physical takings. See generally William Michael Treanor, The Original Understanding of the Takings Clause and the Political Process, 95 Colum. L. Rev. 782 (1995).

166. 47 U.S.C. $§ 251(c)(3)$.

167. 458 U.S. 419 (1982); see also FCC v. Florida Power Corp., 480 U.S. 245 (1987) (considering physical takings claim as to the Pole Attachment Act, which governs the terms by which utility companies must allow cable companies to attach cables to their poles). In Media Gen. Cable of Fairfax, Inc. v. Sequoyah Condominium Council of Co-Owners, 737 F. 
D.C. Circuit's reversals of the FCC's collocation rules on statutory grounds, the theory being that the court could thereby avoid construing the rule as a violation of the physical takings doctrine. ${ }^{168}$ Furthermore, two prominent scholars have recently argued that the physical takings doctrine is the most appropriate home for a constitutional challenge to the 1996 Act's requirements of interconnection and UNE access. ${ }^{169}$

Still, it is not clear how closely the claim would fit under the physical takings doctrine. To the extent that the challenge is aimed at the retail rate structure, it is not clear that one could plausibly allege a direct physical taking at all. Second, even if the court were persuaded that a physical taking had occurred, the real question would then become: Does the price structure allowed to the ILECs amount to just compensation or not? The Takings Clause, as the Supreme Court has said on many occasions, does not prevent takings per se, but rather prevents takings without compensation. ${ }^{170}$ To answer the question of compensation, one would likely have to consult the confiscatory rate doctrine, which will be discussed below. ${ }^{171}$

Supp. 903 (E.D. Va. 1990), the court distinguished Florida Power, saying that it does not support the physical takings doctrine like Loretto does. Id. at 908.

168. E.g., GTE Serv. Corp. v. FCC, 205 F.3d 416, 421, 423, 426 (D.C. Cir. 2000); Bell Atl. Tel. Cos. v. FCC, 24 F.3d 1441, 1445-47 (D.C. Cir. 1994). See also GTE N.W., Inc. v. Pub. Util. Comm'n, 900 P.2d 495, 504 (Or. 1995).

169. Daniel F. Spulber \& Christopher S. Yoo, Access to Networks: Economic and Constitutional Connections, 88 CORNELL L. REV. 885, 947-49, 960-70 (2003) [hereinafter Spulber \& Yoo].

170. See, e.g., First English Evangelical Lutheran Church v. County of Los Angeles, 482 U.S. 304, 314-15 (1987).

171. Spulber and Yoo also argue persuasively and at great length that the bulk of the Supreme Court's precedents make clear that governmental takings must be compensated by the full market value of the thing taken, that market value is becoming more readily calculable in the telecommunications market, and that, therefore, market value should replace the confiscatory rate doctrine to the extent feasible. Spulber \& Yoo, supra note 169 , at 949-59, 970-80. But even if a court could readily calculate the market value for a wide variety of telecommunications equipment and facilities, it is unclear that market value would suffice to compensate the ILECs for the Takings problem that has been identified. That is, the market value of UNEs, whatever that is, would not include any amount of overcharging, as has been done in the past to cross-subsidize more expensive customers. Thus, even if an ILEC is able to obtain the full market value for UNEs, that is no guarantee that it will be fully compensated for universal service and carrier of last resort obligations. 
A second subdoctrine is the regulatory takings doctrine. This doctrine arose in the 1922 decision of Pennsylvania Coal Co. v. Mahon, ${ }^{172}$ in which Justice Holmes wrote for the Court that "while property may be regulated to a certain extent, if regulation goes too far it will be recognized as a taking." ${ }^{173}$ Although this case involved land use restrictions, the holding of Mahon has been extended to numerous government restrictions on other types of property. ${ }^{174}$ In 1978 , the Court added a small bit of clarity to the "too far" test by holding that three factors are of particular relevance: "[t]he economic impact of the regulation" on the property owner, "the extent to which the regulation has interfered with distinct investment-backed expectations," and "the character of the governmental action." 175

Finally, there is the confiscatory rate doctrine, which specifically applies to claims that a regulated rate fails to compensate a public utility for its expenses. Though the regulatory takings and confiscatory rate doctrines differ more in name than in substance, ${ }^{176}$ the confiscatory rate doctrine is likely to be the most apt doctrine on which to rest any takings claim. The

172. 260 U.S. 393 (1922)

173. Id. at 415 (emphasis added).

174. See, e.g., Phillips v. Wash. Legal Found., 524 U.S. 156 (1998) (interest on attorney trust accounts); Concrete Pipe \& Prods. of Cal., Inc. v. Constr. Laborers Pension Trust, 508 U.S. 602 (1993) (pension plans); Bowen v. Gilliard, 483 U.S. 587 (1987) (welfare payments); Connolly v. Pension Benefit Guar. Corp., 475 U.S. 211 (1986); Ruckelshaus v. Monsanto Co., 467 U.S. 986 (1984) (pesticide formulas); United States v. Sec. Indus. Bank, 459 U.S. 70, 78 (1982) (liens on real property); Andrus v. Allard, 444 U.S. 51 (1979) (eagle feathers); Usery v. Turner Elkhorn Mining Co., 428 U.S. 1 (1976) ( black lung benefits).

175. Penn Cent. Transp. Co. v. New York City, 438 U.S. 104, 124 (1978).

176. The Supreme Court has occasionally used the two lines of precedents interchangeably. For example, in one rent control case, the Court looked to confiscatory rate precedents, Pennell v. City of San Jose, 485 U.S. 1, 11-13 (1988), while in another rent control case, the Court looked to its regulatory takings precedents, Yee v. City of Escondido, 503 U.S. 519, 522-23 (1992). As two legal scholars have recently pointed out, a close reading of Supreme Court opinions suggests:

[B]oth lines of precedent may represent a single concept. It is easy to conceptualize a restriction on the amount that one can charge for access to a piece of property as either a restriction on the property's use or as a "public program adjusting the benefits and burdens of economic life to promote the common good." Moreover, similar concerns appear to animate both lines of precedent.

Spulber \& Yoo, supra note 169, at 943-44; see also John N. Drobak, From Turnpike to Nuclear Power: The Constitutional Limits on Utility Rate Regulation, 65 B.U. L. REV. 65, 98 (1985) (asserting that the Court's regulatory takings and confiscatory ratemaking precedents are "equivalent"). 
regulatory takings label is more often applied to those situations in which the government has, by regulation, either deprived a real property owner of all economically viable use of his property or has compelled the owner to surrender the right to exclude others from the use of his property. ${ }^{177} \mathrm{By}$ contrast, the confiscatory rate doctrine by definition relates to an unfair rate structure, which would be precisely the ILEC's complaint.

\section{B. The Confiscatory Rate Doctrine-History and Current Applications}

The confiscatory rate doctrine arose in the late nineteenth century and was based on the notion that, although the state can lawfully regulate prices of public utilities,

it is not to be inferred that this power of limitation or regulation is itself without limit. This power to regulate is not a power to destroy, and limitation is not the equivalent of confiscation. Under pretence of regulating fares and freights, the State cannot require a railroad corporation to carry persons or property without reward; neither can it do that which in law amounts to a taking of private property for public use without just compensation, or without due process of law. ${ }^{178}$

In the early years of the Court's takings jurisprudence, the Court itself took great pains to examine various pricing methodologies as used by regulators. ${ }^{179}$ Thus, in the famous case of Smyth v. Ames ${ }^{180}$ the Court held that regulated entities deserved to receive the "fair value"181 of their investment, and that the Court should look to the "original cost of construction ..., the amount and market value of its bonds and stock, the present as compared with the original cost of construction, [and] the probable earning capacity of the property under particular rates prescribed by statute."182

177. See Lucas v. S. C. Coastal Council, 505 U.S. 1003, 1015 (1992).

178. R.R. Comm'n Cases, 116 U.S. 307, 331 (1886).

179. A survey of the history of rate regulation can be found in the Supreme Court's recent opinion in Verizon Comm., Inc. v. FCC, 535 U.S. 467, 477-89 (2002).

180. 169 U.S. 466 (1898).

181. Id. at 546.

182. Id. at 546-47; see also San Diego Land \& Town Co. v. Jasper, 189 U.S. 439, 442 (1903) ("what the company is entitled to demand, in order that it may have just compensation, is a fair return upon the reasonable value of the property at the time it is being used for the public'") (quoting San Diego Land \& Town Co. v. Nat'l City, 174 U.S. 739, 757 (1899)). 
Beginning in the 1940s, however, the Supreme Court rejected the "fair value" inquiry, following a long line of separate opinions criticizing that theory as uncertain and unworkable. ${ }^{183}$ Instead, the Court held that the Takings Clause can be invoked only where the ultimate outcome is unfair. "The Constitution does not bind rate-making bodies to the service of any single formula or combination of formulas. ... If the Commission's order, as applied to the facts before it and viewed in its entirety, produces no arbitrary result, our inquiry is at an end." ${ }^{184}$ In another case, the Court held that "it is the result reached not the method employed which is controlling. It is not theory but the impact of the rate order which counts. If the total effect of the rate order cannot be said to be unjust and unreasonable, judicial inquiry ... is at an end." 185 The Court still maintains this view: "[A]n otherwise reasonable rate is not subject to constitutional attack by questioning the theoretical consistency of the method that produced it." 186

Instead, the Court laid out the following observations on what a regulated firm has a right to expect:

[T] he investor interest has a legitimate concern with the financial integrity of the company whose rates are being regulated. From the investor or company point of view it is important that there be enough revenue not only for operating expenses but also for the capital costs of the business.... [T] he return to the equity owner should be commensurate with returns on investments in other enterprises having corresponding risks. That return, moreover, should be sufficient to assure confidence in the financial integrity of the enterprise, so as to maintain its credit and to attract capital. ${ }^{187}$

183. The change in theory was instigated by a famous dissent by Justice Brandeis in 1923, in which he argued that the Smyth v. Ames fair value rule "is delusive. In the attempt to apply it insuperable obstacles have been encountered. It has failed to afford adequate protection either to capital or to the public." Missouri ex rel. S.W. Bell Tel. Co. v. Pub. Serv. Comm'n, 262 U.S. 276, 292 (1923); see also McCart v. Indianapolis Water Co., 302 U.S. 419, 428-29 (1938) (Black, J., dissenting) (criticizing fair value); West v. Chesapeake \& Potomac Tel. Co., 295 U.S. 662, 689-90 (1935) (Stone, J., dissenting) (criticizing the fair value rule); Bluefield Water Works \& Improvement Co. v. Pub. Serv. Comm'n, 262 U.S. 679, 695 (1923) (Brandeis, J., concurring in judgment).

184. Fed. Power Comm'n v. Natural Gas Pipeline Co., 315 U.S. 575, 586 (1942); see also Fed. Power Comm'n v. Texaco, Inc., 417 U.S. 380 (1974); Colo. Interstate Gas Co. v. Fed. Power Comm'n, 324 U.S. 581 (1945).

185. Fed. Power Comm'n v. Hope Natural Gas Co., 320 U.S. 591, 602 (1944) (citations omitted).

186. Duquesne Light Co. v. Barasch, 488 U.S. 299, 314 (1989).

187. Hope Natural Gas, 320 U.S. at 603. The Court went on to hold: "Rates which 
Following Hope Natural Gas, the Court most recently opined in Duquesne that "whether a particular rate is 'unjust' or 'unreasonable' will depend to some extent on what is a fair rate of return given the risks under a particular ratesetting system, and on the amount of capital upon which the investors are entitled to earn that return." 188 In Duquesne, Pennsylvania had calculated electric rates by looking primarily at the historical cost of the property/capital in service. ${ }^{189}$ The state did, however, disallow the earning of returns on investments that, although prudent at the time, were not "used and useful." "190 The Court approved, holding "that a state scheme of utility regulation does not 'take' property simply because it disallows recovery of capital investments that are not 'used and useful in service to the public.","191

It is difficult to pin down exactly what would constitute a taking under the Court's jurisprudence. The mere fact that one method of calculating rates was approved in Duquesne does not tell us which of the many possible alternative rates might be unconstitutional. The Court noted in Duquesne that there had been no argument that "these slightly reduced rates jeopardize the financial integrity of the companies, either by leaving them insufficient operating capital or by impeding their ability to raise future capital." 192 But these vague suggestions do not establish just exactly how much damage to financial integrity or to capital-raising ability would count as a taking.

enable the company to operate successfully, to maintain its financial integrity, to attract capital, and to compensate its investors for the risks assumed certainly cannot be condemned as invalid. ..." Id. at 605. This standard was essentially set forth in prior cases as well. See, e.g., Bluefield Water Works, 262 U.S. at 692 (1923) ("A public utility is entitled to such rates as will permit it to earn a return ... equal to that generally being made at the same time and in the same general part of the country on investments in other business undertakings which are attended by corresponding risks and uncertainties ....").

188. Duquesne Light, 488 U.S. at 310.

189. Id. at 312 .

190. Id. Cf. TeX. UTIL. CodE ANN. § 53.051 (Vernon 1998) ("In establishing a public utility's rates, the commission shall establish the utility's overall revenues at an amount that will permit the utility a reasonable opportunity to earn a reasonable return on the utility's invested capital used and useful in providing service to the public in excess of the utility's reasonable and necessary operating expenses.").

191. Duquesne Light, 488 U.S. at 301-02.

192. Id. at 312 . 
On such questions, the Court has unfortunately provided little guidance. ${ }^{193}$ Even in Hope Natural Gas, the Court said that it was not "important to this case to determine the various permissible ways in which any rate base on which the return is computed might be arrived at." 194 This refusal to specify what makes a rate "reasonable" led Justice Jackson to observe in his famous and devastating dissent:

If ... we are to bring judgment of our own to the task, we should for the guidance of the regulators and the regulated reveal something of the philosophy, be it legal or economic or social, which guides us. We need not be slaves to a formula but unless we can point out a rational way of reaching our conclusions they can only be accepted as resting on intuition or predilection. I must admit that I possess no instinct by which to know the "reasonable" from the "unreasonable" in prices and must seek some conscious design for decision.

The Court sustains this order as reasonable, but what makes it so or what could possibly make it otherwise, I cannot learn. ${ }^{195}$

As Justice Scalia pointed out in a similar passage, "We cannot determine whether the payments a utility has been allowed to collect constitute a fair return on investment, and thus whether the government's action is confiscatory, unless we agree upon what the relevant 'investment' is." 196

The problem is that the Hope Natural Gas standard-looking only at ultimate fairness and not at underlying methodology-is mostly incoherent. In order to determine whether the final rate is fair or not, the court must compare that final rate to some sort of benchmark, and in order to determine the benchmark rate of return, the court simply must have some idea of what methodology is constitutionally required. For example, if the Constitution guarantees only that the firm can recover its hypothetically most efficient forward-looking costs, then a rate that is accurately calculated using that methodology will produce a fair ultimate outcome. But if the benchmark for takings purposes is the historical cost experienced

193. See Sean P. Madden, Note, Takings Clause Analysis of Utility Ratemaking Decisions: Measuring Hope's Investor Interest Factor, 58 FoRDHAM L. REV. 427, 436-37 (1989) ("Hope mandates end results that are 'just and reasonable,' but those terms are difficult to define with precision. Moreover, Hope and its progeny provided few criteria by which a reviewing court can judge the end result of a rate order.") (footnotes omitted).

194. Hope Natural Gas, 320 U.S. at 603.

195. Id. at 645-46 (Jackson, J., dissenting).

196. Duquesne Light, 488 U.S. at 317 (Scalia, J., concurring). 
by the firm, then a rate based on forward-looking costs might produce an unconstitutional taking. One simply cannot determine ultimate fairness unless one has a definite point of comparison.

This, though, the Court has declined to do. To quote again from the Court's most recent leading case:

If the rate does not afford sufficient compensation, the State has taken the use of utility property without paying just compensation and so violated the Fifth and Fourteenth Amendments. As has been observed, however, "[h]ow such compensation may be ascertained, and what are the necessary elements in such an inquiry, will always be an embarrassing question." 197

Moreover, the Court has often emphasized the fact-specific nature of a takings inquiry. ${ }^{198}$ In more recent years, the Court has noted that takings claims give rise to "ad hoc, factual inquiries." "199

Richard Pierce has noted that there are three main possibilities for determining fair and constitutional rates: the prudent investment test, the "used and useful" test, and the risk allocation method. ${ }^{200}$ Under the prudent investment test, the court would hold confiscatory any rate that did not allow the utility to recover the costs for capital and facilities investments that were prudent at the time they were made. The "used and useful" test would ask whether the rate fully recompenses the utility for its facilities that are actually used and useful in its ongoing operations at the time the rate is set. ${ }^{201}$ The third option is the risk allocation method, in which the regulator or court attempts to allocate the risks of excess capacity or discontinued facilities between utilities and their consumers. ${ }^{202}$

Pierce argues that we should consider the institutional capabilities of the judiciary when considering what test to apply here ${ }^{203} \mathrm{He}$ is skeptical of

197. Id. at 308 (citations omitted).

198. See, e.g., Bluefield Water Works \& Improvement Co. v. Pub. Serv. Comm'n, 262 U.S. 679, 692 (1923) ("What annual rate will constitute just compensation depends upon many circumstances and must be determined by the exercise of a fair and enlightened judgment, having regard to all relevant facts."); Covington \& Lexington Tpk. Rd. Co. v. Sandford, 164 U.S. 578, 597 (1896) ("In short, each case must depend upon its special facts....").

199. Penn. Cent. Transp. Co. v. New York City, 438 U.S. 104, 124 (1978).

200. Richard J. Pierce, Jr., Public Utility Regulatory Takings: Should the Judiciary Attempt to Police the Political Institutions?, 77 GEO. L.J. 2031, 2049-50 (1989).

201. Id. at 2055 .

202. Id. at 2056.

203. Id. at 2042-47. Cf. generally NeIL K. KOMESAR, IMPERFECT AlternAtives: 
any court's capability to inquire into matters of risk allocation ${ }^{204}$ or of the firm's ability to attract capital on the market. ${ }^{205}$ As for the prudent investment test, "predicting disallowances based on imprudence requires the services of an omniscient political scientist."206

Although the question of judicial capacity is not easy to answer, one suspects that the "used and useful" test might be easiest for judges to

Choosing Institutions in LAw, Economics, And Public Policy (1994) (arguing for wider consideration of institutional capabilities).

204. "The likelihood that reviewing courts will develop a mastery of risk allocation and constrain the process of risk allocation in a tolerably consistent manner seems slight." Pierce, supra note 200, at 2065-66.

205. Id. at 2061-64. Pierce also states:

It is even less likely that courts would be able to administer this form of strong review with tolerable error and resource costs. Every agency decision would turn on specific findings with respect to elusive facts, such as the impact on a firm's future financial condition of an agency's disallowance of all or part of an investment. Most cases also would involve controversial and conflicting interjurisdictional judgments. Reviewing courts would have to engage in detailed review of multiple findings and then decide the proportionate burden of regulatory relief that should be borne by consumers in each jurisdiction.

The results of this process of review would include wide variations attributable to the differing attitudes of liberal and conservative judges. Moreover, many cases would create intractable parochial conflicts between courts of different states. Even if the Supreme Court decided to devote a high proportion of its resources to managing this form of judicial participation in the ratemaking process, it could decide only a small fraction of the many cases announcing inconsistent allocation rules or applying the fact-specific financial impairment test to identical circumstances with different results. Thus, by any standard-substantive effect, resource costs, or error costs-qualifying the used and useful test by applying a strong version of the end result test would be a costly mistake.

Id. at 2064 (footnotes omitted).

206. Id. at 2070. Pierce points to highly disparate results in quite similar cases where judges attempted to inquire into the prudence of prior investments. Id. at 2066-69. He concludes:

$[\mathrm{P}]$ rudence determinations are so dependent on subjective assessments of complicated, ambiguous patterns of conduct that any judicial effort to control the ratemaking process through strict scrutiny of prudence findings would likely entail very high error and resource costs. The deferential substantial evidence test which is applied to all other agency findings would have to be replaced with something that gives reviewing courts far more control over the factfinding process in prudence cases. The only possibility that comes to mind is rejuvenating the old "constitutional fact" doctrine that once required de novo review of all findings with constitutional implications. This would impose a massive burden on scarce judicial resources.

Id. at 2069 (footnotes omitted). But see Madden, supra note 193, at 436-37 (arguing that courts should use the prudent investment test as a constitutional matter). 
implement, as it would merely require the parties to demonstrate whether particular investments were being used to provide local exchange service or not. On the other hand, perhaps the most easily implemented test would be to consider any and all physical facilities owned by the ILECs at present. The obvious objection is that ILECs may have many physical facilities that are either unused or were not a prudent investment at the time it was incurred. But this objection bears less weight in an era when prominent ILECs are subject to price-cap regulation, which provides enormous incentives for ILECs (at least over short-term periods before rates are ultimately adjusted) to construct and deploy facilities in the most efficient manner possible (so as to pocket the additional profits allowable under the cap). ${ }^{207}$ In other words, the existence of price-cap regulation may enable courts to avoid difficult and intransigent inquiries into the prudence of investments, etc., by employing a heuristic assumption that current ILEC facilities were constructed and deployed with something close to maximum efficiency.

As noted above, the Hope Natural Gas Court said that "the return to the equity owner should be commensurate with returns on investments in other enterprises having corresponding risks. ${ }^{208}$ As interpreted by Baumol and Merrill, this inquiry

entails determining (1) the risk of the regulated enterprise; (2) the competitive rate of return available in capital markets on other investments having comparable risks; (3) a projection of the total effect of the rate order on the actual rate of return of the regulated enterprise; and (4) a determination of whether the projected rate of return deviates materially from the competitively required rate of return. ${ }^{209}$

Baumol and Merrill then suggest that the appropriate benchmark of allowable investment be "whatever the regulatory jurisdiction itself deems to be the proper rate base." 210

Adopting the regulatory jurisdiction's benchmark, however, places an enormous thumb on the scale on the side of not finding any takings violations. In any event, there is an element of circularity in this measure of

207. See Verizon Comm., Inc. v. FCC, 535 U.S. 467, 487 (2002) (describing the incentives created by price-cap regulation).

208. Fed. Power Comm'n v. Hope Natural Gas Co., 320 U.S. 591, 603 (1944).

209. William J. Baumol \& Thomas W. Merrill, Deregulatory Takings, Breach of the Regulatory Contract, and the Telecommunications Act of 1996, 72 N.Y.U. L. REV. 1037, 1043-44 (1997) [hereinafter Baumol \& Merrill].

210. Id. at 1044. 
fairness, since the ILEC's level of risk will no doubt be closely correlated to the possibility that regulators will not set rates at a fair level and that courts will fail to recognize a confiscatory taking. Put another way, part of the risk faced by ILECs is precisely that regulators have set in place a selfcontradictory set of pricing systems and that courts might not rule in their favor on the takings issue.

Alternatively, Hope Natural Gas might be interpreted to mean that the court should consider the return available to the firm's stockholders, but it is difficult to see how this makes any sense. The attraction of this sort of test is that it would avoid the following difficult issues: (1) what rate base to look at, and (2) whether to examine historical or replacement value. This test might also be easier for judges to implement with limited time and capacity. On the other hand, to the extent that risk and market returns are already highly correlated, as implied by the predominant Capital Asset Pricing Model ("CAP-M"), ${ }^{211}$ then one would naturally expect to find that any ILEC with a given level of risk ("beta," in stock market lingo) would experience, on average, a similar return compared to other stocks with the same beta. It would be anomalous to find that ILECs incurred lower equity returns than other firms with similar levels of risk; such a finding would be an indication that the level of risk attributed to ILECs had been underestimated. Thus, the stock market return measure seems problematic.

Whatever the methodology, it is clear that if a rate structure actually causes the enterprise to lose money on an ongoing basis, a takings violation has occurred. In the famous case, Brooks-Scanlon Co. v. R.R. Comm'n, Louisiana attempted to require a lumber company to operate a rural railroad route, as part of its larger service operation, even though serving that route would cause the railroad division a loss of more than $\$ 1500$ per month. ${ }^{212}$ Justice Holmes, delivering the opinion of the Court, held "The plaintiff may be making money from its sawmill and lumber business but it no more can be compelled to spend that than it can be compelled to spend any other money to maintain a railroad for the benefit of others who do not care to pay for it." 213

211. The CAP-M was developed in John Lintner, The Valuation of Risk Assets and the Selection of Risky Investments in Stock Portfolios and Capital Budgets, 47 Rev. ECoN. \& StaT. 13 (1965); and William F. Sharpe, Capital Asset Prices: A Theory of Market Equilibrium Under Conditions of Risk, 19 J. FIN. 425 (1964).

212. 251 U.S. 396, 397 (1920).

213. Id. at 399. The Court went on: "The principle is illustrated by the many cases in 
This is relevant because many (if not all) ILECs are designated as "carriers of last resort" under various state laws, which means that they are generally not allowed to (1) refuse local phone service to any customer in any area in which they operate, or (2) discontinue service in an area where there is no other carrier. ${ }^{214}$ As the Court observed over 100 years ago, the Constitution forbids the legislature to "compel parties engaged in legitimate business, and business which cannot be abandoned at will, to so reduce their charges for service as to make the carrying on of that business result in a continued loss." 215 At least two reported federal decisions have approved a state commission's refusal to order geographic deaveraging as to UNE rates, on the grounds that carrier of last resort obligations would leave ILECs in an unfair position. ${ }^{216}$ These carrier of last resort obligations

which the constitutionality of a rate is shown to depend upon whether it yields to the parties concerned a fair return." Id.

214. See, e.g., TEX. UTIL. CodE ANN. § 54.251(a) (Vernon 1998) (requiring the holder of a certificate of convenience and necessity or a certificate of operating authority to "offer all basic local telecommunications services to each customer in the utility's certificated area; and provide continuous and adequate service in that area"); Id. § 54.253(d) (providing that a holder of a certificate of operating authority may not cease operations unless there is another provider serving the area); Cal. Pub. Utilities Comm'n, Rulemaking on the Commission's Own Motion into Universal Service and to Comply with the Mandates of Assembly Bill 3643, Decision No. 96-10-066, 1996 Cal. PUC LEXIS 1046, at**292-93 (Oct. 25, 1996) (discussing California's carrier of last resort obligations).

215. Reagan v. Farmers' Loan \& Trust Co., 154 U.S. 362, 409 (1894). The Court considered a similar argument in the Permian case:

The producers have urged, and certain of this Court's decisions might be understood to have suggested, that if maximum rates are jointly determined for a group or area, the members of the regulated class must, under the Constitution, be proffered opportunities either to withdraw from the regulated acitivity or to seek special relief from the group rates...

It is enough for present purposes that the Commission has in other circumstances allowed abandonment, and that it has indicated that it will, in appropriate cases, authorize it here.

Permian Basin Area Rate Cases, 390 U.S. 747, 770-71 (1968) (emphasis added).

216. AT\&T Comm. of the Pac. N.W., Inc. v. U.S. West Comm., Inc., 31 F. Supp.2d 861, 865 (D. Or. 1998) ("Under present rules, U.S. West must charge the same retail rate for service, regardless of how much it costs to serve a particular customer. In addition, U.S. West is required to provide service to anyone in its service area who requests it, whereas competitors such as AT\&T can solicit the most profitable customers while leaving the remainder for U.S. West to serve."); MCI Telecomm. Corp. v. GTE N.W., Inc., 41 F. Supp.2d 1157, 1171 (D. Or. 1999) ("an ILEC is legally obligated to service all customers within its territory, at the same fixed price. Consequently, MCI and other CLECs could solicit the most profitable customers, leaving the ILEC to service the unprofitable accounts the CLECs do not want.”). Note that in a recent Fifth Circuit case in which GTE challenged 
should, therefore, lend support to the theory that ILECs may be experiencing a taking.

One might expect the FCC and state commissions (not to mention the CLECs) to be highly resistant to the takings claim I have outlined. Their argument in response would probably proceed as follows: An ILEC may have experienced lower than usual rates of return on its investments (however calculated), but that does not mean that federal or state rate regulation is the cause. The telecom market is in trouble generally, and on top of that, the ILECs are experiencing the pressure of increasing competition. In fact, as the ILECs' traditional monopoly is eroded by competition, one should expect that their rate of return will decrease.

To be able to respond to that counterargument, a plaintiff ILEC will find it crucial to present hard figures on the actual costs of service, the effects of state-mandated retail rates, the effects of UNE rates, and figures from state and federal universal service funds. ${ }^{217}$ Only such an evidentiary showing would suffice to clearly establish the harmful impact of the current structure. ${ }^{218}$ The plaintiff ILEC would also be wise to procure

the FCC's first universal service order, the FCC itself argued that "GTE's problems stem not from bundling but from state-imposed "carrier of last resort' ("COLR") requirements, which prohibit [ILECs] such as GTE from disconnecting low-profit consumers and leave [ILECs] vulnerable to outside competition." Tex. Office of Pub. Util. Counsel v. FCC, 183 F.3d 393, 420 (5th Cir. 1999). The Fifth Circuit took a dim view of this argument from the FCC, noting that eliminating COLR requirements would undermine universal service. But this poses no barrier to an ILEC presenting the argument that COLR requirements exacerbate the difficulties that ILECs face in a competitive marketplace.

217. Hard-and-fast numbers would be necessary to avoid dismissal on ripeness grounds, the fate that has befallen almost all takings challenges related to TELRIC or universal service under the 1996 Act. See, e.g., Verizon Comm., Inc. v. FCC, 122 S. Ct. 1646, 167980 (2002); Alenco Comm., Inc. v. FCC, 201 F.3d 608, 624 (5th Cir. 2000); Iowa Utilities Bd. v. FCC, 219 F.3d 744, 754 (8th Cir. 2000), rev'd on other grounds, Verizon, 122 S. Ct. 1646; Tex. Office of Pub. Util. Counsel v. FCC, 183 F.3d 393, 428-29 (5th Cir. 1999); Iowa Utils. Bd. v. FCC, 120 F.3d 753, 818 (8th Cir. 1997), rev'd \& remanded in part on other grounds, sub nom AT\&T Corp. v. Iowa Utils. Bd., 525 U.S. 366 (1999); U.S. West Comm., Inc. v. Garvey, No. Civ. 97-913 ADM/ALB, 1999 U.S. Dist. LEXIS 22042, at*107 (D. Minn. Mar. 30, 1999); GTE S., Inc. v. Morrison, 6 F. Supp. 2d 517, 530 (E.D. Va. 1998); MCIMetro Access Transmission Servs., Inc. v. GTE N.W., Inc., Nos. C97-742WD, C97905WD, C97-928WD, 1998 U.S. Dist. LEXIS 11335, at **18-19 (W.D. Wash. Jul 7, 1998); S.W. Bell Tel. Co. v. AT\&T Comm. of the Southwest, Inc., No. A 97-CA-132 SS, 1998 U.S. Dist. LEXIS 15637, at**39-44 (W.D. Tex. Aug. 31, 1998).

218. $C f$. Rural Tel. Coalition v. FCC, 838 F.2d 1307, 1313 (D.C. Cir. 1988) (holding that there was no taking involved in the FCC's decision to allocate twenty-five percent of nontraffic sensitive costs to interstate carriers; carriers had not shown any facts 
econometricians who could testify to the causal relationship between the current regulatory structure and any economic problems that an ILEC has experienced.

In so doing, it would not be enough for an ILEC to argue that its business operations have become less profitable than those of its competitors. As the Court said in a famous ratemaking case, "No constitutional objection arises from the imposition of maximum prices merely because "high cost operators may be more seriously affected... than others." 219 Nor would it be sufficient to show that the "fixing of prices... may reduce the value of the property which is being regulated." 220 "All that is protected against, in a constitutional sense, is that the rates ... be higher than a confiscatory level." 221 Thus, the ILEC must show an actual unfair result from the combination of cost-based UNE rates, universal service obligations, and a changing customer base.

An additional wrinkle is the old case of Baltimore \& Ohio Railroad Co. v. United States, ${ }^{222}$ in which the Court held that "[s]o long as a railroad is not caused by such [rate] regulations to lose money on its over-all business, it is hard to think that it could successfully charge that its property was being taken for public use "without just compensation.", 223 This case seems to be an outlier, however, and no other precedent suggests that a confiscatory rate is constitutional as long as the business in question

demonstrating a confiscation); Gabel \& Rosenbaum, supra note 73, at 267-68 (arguing that ILECs' rate of return on regulated investment is high enough not to be a taking).

219. Permian Basin Area Rate Cases, 390 U.S. at 769 (quoting Bowles v. Willingham, 321 U.S. 503, 518 (1944)).

220. Fed. Power Comm. v. Hope Natural Gas Co., 320 U.S. 591, 601 (1944). In one early case, the Court noted that the mere failure to produce a profit did not necessarily make a rate confiscatory, because

there may have been extravagance and a needless expenditure of money; there may be waste in the management ... The construction may have been at a time when material and labor were at the highest price, so that the actual cost far exceeds the present value; the road may have been unwisely built, in localities where there is no sufficient business to sustain a road.

Reagan v. Farmers' Loan \& Trust Co., 154 U.S. 362, 412 (1894).

221. Fed. Power Comm. v. Texaco, Inc., 417 U.S. 380, 391-92 (1974) (footnotes omitted).

222. 345 U.S. 146 (1953).

223. Id . at 148. The Court went on to say, "And so long as rates as a whole afford railroads just compensation for their over-all services to the public the Due Process Clause should not be construed as a bar to the fixing of noncompensatory rates for carrying some commodities when the public interest is thereby served." Id. at 150 . 
manages to make up the loss from other operations. ${ }^{224}$ Such a rule would make no sense in today's world of integrated business operations. Indeed, modern courts do not follow the above principle, as is shown by a recent case in which the Sixth Circuit Court of Appeals struck down a Michigan law that froze regulated telephone rates for three years. ${ }^{225}$ After holding that the price freeze was confiscatory, the court noted that "although the plaintiffs have other unregulated income streams, they are not required to subsidize their regulated services with income from rates either deemed to be competitive, or with revenues generated from unregulated services." 226

\section{Recent Developments}

This section analyzes several recent circuit court cases involving confiscatory rate claims.

In perhaps the most sophisticated application of modern takings doctrine to a telecommunications carrier, the D.C. Circuit addressed a challenge to the FCC's rate base calculation for interstate services. ${ }^{227}$ The FCC had determined BOC revenue requirements by using an equation: ( $I x$ $r)+C=R$, where $\mathrm{I}$ is the rate base, $\mathrm{r}$ is the rate of return, $\mathrm{C}$ is operating costs, and $\mathrm{R}$ is the total revenue. ${ }^{228}$ Much of the controversy focused on the rate of return, which the FCC had calculated by using discounted cash flow methodology. ${ }^{229}$ Though the D.C. Circuit ultimately held for the FCC, it considered a range of factors under the Hope Natural Gas standard, including the lack of "any steep decline in share prices," ${ }^{230}$ and the fact that

224. Baumol and Merrill argue that any proper takings analysis should consider the fact that the 1996 Act allowed the regional Bell companies, subject to certain restrictions, to enter the long distance market. Baumol \& Merrill, supra note 209, at 1060. They say:

If the same statute that takes away local revenues with one hand returns new interstate revenues with the other, it makes no sense to slice up the same asset (the LEC's network) into different jurisdictional components and then declare a taking in the part that is losing revenue while ignoring the other side of the equation.

Id. at 1060-61.

225. Mich. Bell Tel. Co. v. Engler, 257 F.3d 587 (6th Cir. 2001).

226. Id. at 594 (citations omitted); see also Guar. Nat'l Ins. Co. v. Gates, 916 F.2d 508, 512 (9th Cir. 1990) (invalidating an insurance rate law that failed "to guarantee a constitutionally required fair and reasonable return").

227. Ill. Bell Tel. Co. v. FCC, 988 F.2d 1254 (D.C. Cir. 1993).

228. Id. at 1258 .

229. Id. at 1259.

230. Id. at 1261. 
the FCC had considered "evidence of the rate of returns for other companies," i.e., to other companies similarly ranked within the S\&P $400{ }^{231}$ There was also a challenge to the FCC's use of the "used and useful" rule in calculating the rate base. ${ }^{232}$ Again, the D.C. Circuit found for the FCC, because there had simply "been no demonstration that the FCC's rate base policy threatens the financial integrity of [plaintiffs] or otherwise impedes their ability to attract capital." ${ }^{233}$

In a 1990 case, the Ninth Circuit considered a Nevada law that rolled back automobile insurance rates to a level fifteen percent below the July 1, 1988 levels, and froze rates at that point until October 1, 1990. ${ }^{234}$ The insurance companies sued in federal district court, claiming that this law "violate[d] due process requirements because it prohibit[ed] rate relief to avoid confiscatory results," and that it "would [have] deprive[d] each of the plaintiffs of property and other rights in violation of the due process and taking clauses." 235

Nevada argued that one of its insurance statutes provided a sufficient guarantee that the rates would be high enough to meet the Constitution's requirements. The statute specifically said that " "[r]ates must not be excessive, inadequate, or unfairly discriminatory.""236 The term "inadequate," in turn, was defined as follows: "“[r]ates are inadequate if they are clearly insufficient, together with the income from investments attributable to them, to sustain projected losses and expenses in the class of business of which they apply." ${ }^{237}$ Nevada thus argued that because it statutorily guaranteed that insurance rates would be "adequate" in the sense of covering all losses and expenses, the rates were therefore constitutional. ${ }^{238}$

The Ninth Circuit disagreed, saying that this Nevada law "guarantees only that an insurer will break even; it does not guarantee the constitutionally required "fair and reasonable return.""239 In other words,

231. Id. at 1262 .

232. Id. at 1263.

233. Id.

234. Guar. Nat'l Ins. Co. v. Gates, 916 F.2d 508 (9th Cir. 1990).

235. Id. at 510 (quoting the complaint from the insurance companies).

236. Id. at 515 (quoting NEV. REV. STAT. 686B.050(1) (1987)).

237. Id. (quoting NeV. REV. Stat. 686B.050(3) (1987)).

238. Id.

239. Id. (citations omitted). 
the Constitution guarantees a fair return to investors, not merely that the enterprise will break even and be able to cover its costs. The court therefore enjoined the implementation of the statute. ${ }^{240}$

More recently, the Sixth Circuit considered a Michigan law freezing regulated telephone rates at their May 1, 2000 level until the end of 2003. ${ }^{241}$ The court noted that the Constitution protects against confiscatory rates (though, the court focused on the Due Process Clause as opposed to the Takings Clause) ${ }^{242}$ Like Nevada, Michigan attempted to argue that various statutes guaranteed a return sufficient to meet the Constitution's standard. Specifically, Michigan pointed to statutes providing that "the rates for basic local exchange service shall be just and reasonable," and defining "reasonable rate" as "a rate that is not inadequate. . . A rate is inadequate if it is less than the total service long run incremental cost of providing the service [TSLRIC]." 243

The court's response was that the Constitution guarantees more than the recovery of TSLRIC: "The definition [of 'adequate'] clearly does not guarantee a constitutionally adequate rate of return for regulated telephone service providers because it merely permits telephone service providers to cover costs, and does not ensure a fair and reasonable rate of return on investment." 244 The court further discussed the definition of TSLRIC in the Michigan statute, and concluded that under that definition, "a rate would only be inadequate if it was set below the cost incurred by the service provider. This clearly does not satisfy the constitutional standard... because it merely ensures cost recovery without guaranteeing a fair and reasonable rate of return on investment." ${ }^{245}$ Based on these considerations, the court affirmed the district court's injunction against the statute. ${ }^{246}$

The Fifth Circuit, in 1999, heard a massive set of challenges to various features of the federal universal service programs. ${ }^{247}$ Three of the challenges involved takings claims. The first takings claim, brought by GTE and Southwestern Bell, was that the federal USF failed to provide

240. Id. at 516 .

241. Mich. Bell Tel. Co. v. Engler, 257 F.3d 587 (6th Cir. 2001).

242. Id. at 593.

243. Id. at 594 (quotations omitted).

244. Id.

245. Id. at 595 .

246. Id. at 600 .

247. Tex. Office of Pub. Util. Counsel v. FCC, 183 F.3d 393 (5th Cir. 1999). 
enough support for high-cost areas because its support was based not on the difference between revenue and actual costs, but on the difference between revenue and the "forward-looking cost models based on the 'least cost, most efficient' carrier." 248 The court disposed of the takings analysis in a footnote that read:

GTE claims that implementing the forward-looking cost methodology will force [ILECs] to operate at a loss, and this constitutes an unconstitutional taking under Brooks-Scanlon. GTE's claim has no merit; it has not shown that a taking has occurred or that any taking will be permanent or would be so serious as to be considered "confiscatory."...

Unlike the situation in Brooks-Scanlon, the circumstance here is that the regulatory entity setting the rules, the FCC, is not requiring the [ILECs] to remain open or to charge low rates, thereby forcing them to operate at a permanent loss. ${ }^{249}$

Another entity-Celpage, a paging carrier-challenged an FCC requirement that commercial mobile radio services contribute to the federal USF. ${ }^{250}$ The court swiftly rejected the takings portion of this claim as not ripe because Celpage had not used any of the FCC's administrative procedures for seeking compensation. ${ }^{251}$ The court also noted that Celpage had failed to demonstrate a taking under the Supreme Court's three-part test for regulatory takings (i.e., the economic impact on the claimant, the interference with investment-backed expectations, and the character of the government action). ${ }^{252}$ The court did not explain its choice to refer to the regulatory takings analysis here rather than the confiscatory rate doctrine.

The third takings claim was also by GTE and was aimed at the FCC's decision in that particular order to delay implementation of the federal USF support program until January 1, 2000. ${ }^{253}$ GTE claimed "that the FCC's decision to leave [ILECs] exposed to local competition without first implementing the new universal service plan results in a severe reduction of its revenues from local service." 254 The court rejected this claim,

248. Id. at 410-11 (footnotes omitted).

249. Id. at $413 \mathrm{n} .14$ (citations omitted).

250. Id. at 426 .

251. Id. at 428-29.

252. Id. at 429 n.59 (citing Connolly v. Pension Benefit Guar. Corp., 475 U.S. 211, 225 (1986)).

253. Id. at 435 .

254. Id. at 437 . 
however, on the grounds that GTE "failed to meet the requirements of Duquesne, because it cannot show that it will lose any revenue at all, much less enough to constitute a taking under more recent precedent." 255 The court continued, saying that "GTE's reliance on Brooks-Scanlon is misplaced, because we will not apply the rule in that case to transitional or temporary periods." 256

Finally, the Eleventh Circuit in 2002 considered a takings claim related to the 1996 Act's amendments of the Pole Attachment Act, which requires power companies to lease space on utility poles to cable television companies. ${ }^{257}$ The court began the takings analysis by noting that because Congress had mandated physical access to the utility poles, the "confiscatory rate" doctrine was not to be applied. Rather, "a different analytical hat must be worn": that of the physical takings doctrine. ${ }^{258}$ Having concluded that a per se physical taking was present, the court quickly moved to the question of just compensation, ${ }^{259}$ saying that it would address whether marginal cost satisfied the Constitution's requirements. ${ }^{260}$

As to this question, the court reasoned that where the available pole space is sufficiently large to be practically nonrivalrous, marginal cost should suffice to compensate the pole owner. ${ }^{261}$ The court concluded:

In short, before a power company can seek compensation above marginal cost, it must show with regard to each pole that (1) the pole is at full capacity and (2) either (a) another buyer of the space is waiting in the wings or (b) the power company is able to put the space to a higher-valued use with its own operations. ${ }^{262}$

Unless those factors are shown, said the court, "there is no "lost opportunity' foreclosed by the government."263

In sum, the general disarray of the caselaw is notable. Courts have not settled on a definite and precise means of determining what constitutes a confiscatory rate. When the law at issue allows only the recovery of

255. Id.

256. Id.

257. Ala. Power Co. v. FCC, 311 F.3d 1357, 1360 (11th Cir. 2002).

258. Id. at 1367.

259. Id. at 1368 .

260. Id. at 1369.

261. Id. at 1369-70.

262. Id. at 1370.

263. Id. at 1371 . 
[Vol. 56

forward-looking costs, with no element of profit, courts do find that the rate is confiscatory, as was the case in Michigan Bell Telephone Co. v. Engler ${ }^{264}$ and Guaranty National Insurance Co. v. Gates. ${ }^{265}$ But when the rate is not as patently Spartan as in those cases, courts are more reluctant to find any confiscatory takings in the absence of hard, concrete evidence showing the actual effect on the firm's revenues.

\section{CONCLUSION}

Local phone companies are trapped between two utterly contrary pricing schemes - the averaged retail rate system by which they are obligated to serve all customers at roughly equal rates, and the wholesale system by which they are obligated to sell access to their competitors at hypothetical measures of cost. The contradiction between these two pricing systems could easily produce a "confiscatory rate" in violation of the Takings Clause of the United States Constitution.

264. 257 F.3d 587 (6th Cir. 2001).

265. 916 F.2d 508 (9th Cir. 1990). 